\title{
Spatial and temporal variation of historical anthropogenic NMVOCs emission inventories in China
}

\author{
Y. Bo, H. Cai, and S. D. Xie \\ College of Environmental Sciences and Engineering, State Key Joint Laboratory of Environmental Simulation and Pollution \\ Control, Peking University, Beijing, China
}

Received: 7 April 2008 - Published in Atmos. Chem. Phys. Discuss.: 11 June 2008

Revised: 13 October 2008 - Accepted: 3 November 2008 - Published: 10 December 2008

\begin{abstract}
Multiyear emission inventories of anthropogenic NMVOCs in China for 1980-2005 were established based on time-varying statistical data, literature surveyed and model calculated emission factors, which were further gridded at a high spatial resolution of $40 \mathrm{~km} \times 40 \mathrm{~km}$ using the GIS methodology. Results show a continuous growth trend of China's historical NMVOCs emissions during the period of 1980-2005, with the emission increasing by 4.2 times at an annual average rate of $10.6 \%$ from $3.91 \mathrm{Tg}$ in 1980 to 16.49 $\mathrm{Tg}$ in 2005. Vehicles, biomass burning, industrial processes, fossil fuel combustion, solvent utilization, and storage and transport generated $5.50 \mathrm{Tg}, 3.84 \mathrm{Tg}, 2.76 \mathrm{Tg}$, $1.98 \mathrm{Tg}, 1.87 \mathrm{Tg}$, and $0.55 \mathrm{Tg}$ of NMVOCs, respectively, in 2005. Motorcycles, biofuel burning, heavy duty vans, synthetic fibre production, biomass open burning, and industrial and commercial consumption were primary emission sources. Besides, source contributions of NMVOCs emissions showed remarkable annual variation. However, emissions of these sources had been continuously increasing, which coincided well with China's economic growth. Spatial distribution of NMVOCs emissions illustrates that high emissions mainly concentrates in developed regions of northern, eastern and southern coastal areas, which produced more emissions than the relatively underdeveloped western and inland regions. Particularly, southeastern, northern, and central China covering $35.2 \%$ of China's territory, generated $59.4 \%$ of the total emissions, while the populous capital cities covering merely $4.5 \%$ of China's territory, accounted for $24.9 \%$ of the national emissions. Annual variation of regional emission intensity shows that emissions concentrating in urban areas tended to transfer to rural areas year by year. More-
\end{abstract}

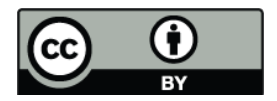

Correspondence to: S. D. Xie (sdxie@pku.edu.cn) over, eastern, southern, central, and northeastern China were typical areas of high emission intensity and had a tendency of expanding to the northwestern China, which revealed the transfer of emission-intensive plants to these areas, together with the increase of biomass open burning.

\section{Introduction}

Nonmethane volatile organic compounds (NMVOCs), which can be stored and react in the air, are a large number of different species of organic compounds with high vapor pressures and low boiling points. NMVOCs have an important influence on the formation of photochemical smog, secondary organic aerosols, and organic acids in the air, and they are severely harmful to human health (Boeglin et al., 2006). Therefore, research on the source and emission characteristics of NMVOCs has been an important issue in atmospheric chemistry studies, which not only provides scientific basis for the control of local photochemical smog pollution and for the prevention and control of acid rain, but also has a profound impact on systematic study on atmospheric chemical reactions, and on the assessment and forecast of the possible change of atmospheric environment on the global scale.

NMVOCs are emitted from both biogenic and anthropogenic sources (Altshuller, 1991; Field et al., 1992). Biogenic sources mainly emit isoprene and monoterpene, while anthropogenic sources exhaust almost all species of NMVOCs. Though globally biogenic sources generated much more emissions (1150 Tg; Guenther et al., 1995) than anthropogenic sources (142 Tg; Seinfeld et al., 1998), anthropogenic NMVOCs emissions dominate in the total emissions on the urban and regional scale (Atkinson, 2003).

Published by Copernicus Publications on behalf of the European Geosciences Union. 
Since 1989, Europe, the US, Australia and other developed countries have begun to compile the native NMVOCs emission inventories (Lubkert and Detilly, 1989; Loibl et al., 1993), and have estimated global NMVOCs emission inventory including China (Piccot et al., 1992). Besides, some reseachers paid special attention to estimating China's NMVOCs emission inventory. Klimont et al. (2002) developed China's NMVOCs emission inventory in 1990, 1995, and 2000 on the provincial level for the first time, based on foreign emission factors and estimated activity data. During the TRACE-P and the ACE-Asia experiments, Streets et al. (2003) estimated China's anthropogenic NMVOCs emissions in 2000, which were based on Klimont's results and further considered the source of savanna and forest burning. Regarding the REAS inventory established by Ohara et al. (2007), NMVOCs emissions in China for 1995 and 2000 came from the results of Klimont et al. (2002) and Streets et al. (2003). In addition, they estimated the NMVOCs emissions for the period 1980-2003 by an extrapolation of the emissions in 1995 and 2000, using a proxy indicator per sector. Chinese scholars also carried out some research. Zhang et al. (2000) demonstrated the spatial distribution of hydrocarbon emission from stationary sources in the Yangtze River Delta. Li et al. (2003) used MOBILE 5 model to estimate the NMVOCs emissions from road traffic in China in 1995. Shen et al. (2006) estimated the VOCs emissions from China's gas stations in 2002. Cai and Xie (2007) calculated the NMVOCs emission factors of various vehicle categories under driving conditions of urban, rural and freeway for each province of China, using COPERT III model, and established China's vehicular emission inventory including NMVOCs emissions for the period of 1980-2005, which was further gridded at a high spatial resolution of $40 \mathrm{~km} \times 40 \mathrm{~km}$ using the Geographic Information System (GIS) methodology.

As described above, international scientists took the lead in developing China's NMVOCs emission inventories, and Chinese scholars also contributed to some anthropogenic emission results. However, there were significant differences between the results, and those inventories mostly focused on China's emissions for a single or few years. Thus, the aim of this study is to develop China's historical NMVOCs emission inventories at a high spatial resolution. In the process of establishing China's NMVOCs emission inventory, locally measured emission factors for anthropogenic NMVOCs emission sources were selected, and the emission factors adopted by Europe, America and other developed countries were chosen based on specific hypotheses. Furthermore, most activity data were obtained by referring to firsthand statistical data in China. Thus, anthropogenic NMVOCs emission inventories in China were developed on the county level for the period of 1980-2005, which were further gridded at a high spatial resolution of $40 \mathrm{~km} \times 40 \mathrm{~km}$ based on the GIS methodology.

\section{Methodology}

\subsection{Estimation and allocation of emissions}

\subsubsection{Emission estimation}

The emission sources were classified into a total of six sources of vehicles, fossil fuel combustion, biomass burning, industrial processes, storage and transport, and solvent utilization, according to the actual situation of anthropogenic NMVOCs emissions in China. Vehicular emissions were calculated based on the emission factors, the population of vehicles, and the corresponding mileage traveled for each vehicle category. The emission estimation of other sources was based on annual average rates of emission related activities, detailed emission factors, and removal efficiency for each source. Thus, the total NMVOCs emissions were estimated by Eq. (1).

$$
\begin{aligned}
Q_{m}= & \sum\left(P_{m, n} \times M_{n, j} \times E F_{n, j}\right) \\
& +\sum A_{m, i} \times E F_{i} \times\left(1-R_{i}\right)
\end{aligned}
$$

where: $Q_{m}$ is the NMVOCs emission $(\mathrm{Mg})$ in province $m$; $n$ is a certain vehicle category; $j$ is a certain driving cycle; $i$ is the other sources excluding vehicles, i.e. fossil fuel combustion, biomass burning, industrial processes, storage and transport, and solvent utilization. For vehicular emission, $P_{m, n}$ is the population of vehicles in category $n$ in province $m ; M_{n, j}$ is the annual mileage (kilometers) for vehicles in category $n$ under driving cycle $j$; and $E F_{n, j}$ is the emission factor $(\mathrm{g} / \mathrm{km})$ of vehicles for category $n$ under driving cycle $j ; A_{m, i}$ is the activity rate of source $i$ in province $m ; E F_{i}$ is the emission factor of source $i$; and $R_{i}$ is the removal efficiency of source $i$.

Upon the consideration of the fact that the economic development plans in China have been compiled in every five years, with a complete and systematic summary conducted in the last year of each five-year-plan period, say, 1980 and 1985. Therefore, the anthropogenic NMVOCs emission inventories in China were estimated by an interval of five years for the period of 1980-2005 in this study, since the statistical data were relatively complete and accurate in the last year of each five-year-plan period. Specifically, the related activity data required by the compilation of the emission inventory were obtained from the provincial statistical data covering 31 provinces, excluding Taiwan, Hong Kong, and Macao.

The NMVOCs emission factors of the anthropogenic sources excluding vehicles were mainly obtained from the recently measured data, literatures and the Compilation of Air Pollutant Emission Factors, which was usually called the AP42 Report (EPA, 1995). Though the industrialization and urbanization in China have been speeding up, the fact that there is a gap of the technical levels and resource utilization efficiency between China and developed countries must be recognized. Besides, there is also a tremendous gap between different regions of China. For example, there were notable 
differences in the technical innovation and resource utilization efficiency between the developed eastern China and the underdeveloped western China, and between urban areas and rural regions. Thus, the emission factors of the same sources in different parts of China differred. Taking into account of such aspects, the technical levels in China were about ten years behind those in the developed countries. Therefore, the emission factors in a given year in China were selected from the emission factor data ten years before for the same sources in the AP42 Report, instead of selecting the renewed emission factor data that represent the current emission levels in the developed countries.

Moreover, the annual variation of emission factors for each source before 2005 was considered. For the sources of fossil fuel combustion and industrial processes, it was assumed that the NMVOCs emissions per unit of fuel consumed were stable, and the emission factor of each sector was directly proportional to the annual energy consumption per production. Thus, emission factors for industrial processes and fossil fuel combustion before 2005 were adjusted based on the determined emission factors for 2005, using Eq. (2).

$E F^{\prime}=\frac{C_{a}}{C_{0}} \times E F_{0}$

where: $E F^{\prime}$ is the modified emission factor of each subsector in year $a$; $C_{a}$ is the annual energy consumption per production of each subsector in year $a ; C_{0}$ is energy consumption per production of each subsector in 2005; and $E F_{0}$ is the emission factor of each subsector in 2005.

Regarding the source of solvent utilization, it was assumed that the emission factors were positively correlated with annual income per capital. Thus, the emission factors for this source before 2005 were estimated based on the determined emission factors for 2005, using Eq. (3).

$E F^{\prime \prime}=\frac{I_{b}}{I_{0}^{\prime}} \times E F_{0}^{\prime}$

where: $E F^{\prime \prime}$ is the modified emission factor of each subsector of solvent utilization in year $b ; I_{b}$ is the annual income per capital in year $b ; I_{0}$ is the annual income per capital in 2005; and $E F_{0}$ ' is the emission factor of each subsector in 2005.

Emission factors of biomass open burning, and storage and transport were assumed to remain constant over the years, because the way of biomass open burning and the means of the storage and transport of organic solvent in China were never remarkably improved.

\subsubsection{Emission allocation}

The NMVOCs emissions of each anthropogenic source in each province of China were firstly calculated, followed by further allocation to the county level based on a top-down approach. Upon the compilation of the national emission inventories based on provincial calculations, county level
Table 1. Proxy variables used for allocating provincial emissions from each source to the county level.

\begin{tabular}{|c|c|}
\hline Proxy variable & Emission source category \\
\hline $\mathrm{GDP}^{\mathrm{a}}$ & $\begin{array}{l}\text { vehicles, industrial processes, } \\
\text { storage and transport, } \\
\text { fossil fuel combustion }\end{array}$ \\
\hline Population $^{\mathrm{b}}$ & solvent utilization \\
\hline Crops seeded area ${ }^{a}$ & biomass burning \\
\hline
\end{tabular}

a data from China County (City) Social Economic Statistical Yearbooks (2001, 2006), China Agriculture Yearbooks (1996, 2001, 2006), and provincial statistical yearbooks in 1996.

b data from China Sstatistical Yearbooks (1996, 2001, 2006).

emissions were calculated by allocating provincial inventories based on proxy variables of GDP, population, and crop seeded area, using Eq. (4).

$E_{i, m, n}=\frac{T_{n}}{\sum_{n=1} T_{n}} \times E_{i, m}$

where: $E_{i, m}$ is the emission $(\mathrm{Mg})$ of source $i$ in province $m ; E_{i, m, n}$ is the emission $(\mathrm{Mg})$ of source $i$ in county $n$ of province $m$; and $T_{n}$ is the GDP, population, or crop seeded area in county $n$. The relationship between emission sources and proxy variables is shown in Table 1.

Upon the allocation of provincial emissions to counties, the latitude and longitude projected map of China was gridded at a resolution of $40 \mathrm{~km} \times 40 \mathrm{~km}$ using Mapinfo, a GIS software, which further calculated the ratios of the areas of each county that fell over various grid cells to the area of that county. Then, the emission of that county was allocated to each grid cell based on the calculated ratios. Finally, the emissions from various counties within a grid cell were aggregated, which was the total emission of that grid cell.

\subsection{Compilation of emission factors and activity data}

\subsubsection{Vehicles}

Emission factors of each vehicle category were calculated by using COPERT III programme, a widely used tool for estimation of emission factors at European level for on-road transportation (EEA, 2000). It was suitable for estimating China's vehicular emissions because the dominant vehicle manufacturing technologies in China originated from European technologies and vehicle emission regulations implemented in China had been almost the same as those performed in Europe (Xie et al., 2006). In addition, compared with MOBILE models, the results calculated by COPERT fit better with the measured emission factors in China (Song and Xie, 2006), and COPERT was more applicable in countries with different emission regulations and deficient transportation data, and it was well used to develop high spatial 
Table 2. China's vehicle mileage travelled $(\mathrm{km})$ of each vehicle category based on literatures.

\begin{tabular}{lllllllll}
\hline PC & MB & Taxi & LDV $^{1}$ & LDV $^{2}$ & HDV & Coaches & Buses & MC \\
\hline $31510 \pm 8942$ & 20002 & 153623 & $29623 \pm 8343$ & $32983 \pm 6643$ & 55680 & 51040 & 104507 & $11554 \pm 2314$ \\
\hline
\end{tabular}

PC: Passenger cars; MB: Microbuses; LDV¹: Gasoline Light Duty Vans; LDV²: Diesel Light Duty Vans; HDV: Heavy Duty Vans; MC: Motorcycles.

Table 3. Vehicle mileage travelled $(\mathrm{km})$ of each vehicle category from 1980 to 2005 .

\begin{tabular}{lllllll}
\hline Vehicle categories & 1980 & 1985 & 1990 & 1995 & 2000 & 2005 \\
\hline Passenger cars & 25000 & 25000 & 30000 & 35000 & 37500 & 40000 \\
Light-duty vans & 20000 & 22000 & 25000 & 27500 & 30000 & 35000 \\
Heavy duty vans & 40000 & 40000 & 50000 & 52500 & 55000 & 57500 \\
Buses and coaches & 60000 & 60000 & 65000 & 65000 & 70000 & 70000 \\
Motorcycles & 10000 & 10000 & 11000 & 12000 & 13000 & 13500 \\
\hline
\end{tabular}

and temporal resolution emission database (Zachariadis and Samaras, 1999). Therefore, COPERT III programme was used to calculate the emission factors of NMVOCs emissions in each province of China for the period of 1980-2005 under the driving cycles of urban, rural and freeway. The detailed methodology was referred to the established methodology (Cai and Xie, 2007).

According to the actual situation in China, vehicles were classified into nine categories of small-size gasoline cars, small-size petrol cars, middle and large-size passenger cars, gasoline light duty vans, diesel light duty vans, gasoline middle duty vans, diesel middle duty vans, diesel heavy duty vans and motorcycles, the population data of which were obtained from the Chinese annual statistical yearbooks.

Another important parameter required determination was the annual vehicle miles travelled (VMT). The VMT data were estimated based on the annual average data reported in literatures (Zhang et al., 2004; He, 1999; Hu et al., 2002; Yu et al., 2008; Ye et al., 2007; Fu et al., 2008), which were summarized in Table 2. Upon the consideration that the road length had increased from $890000 \mathrm{~km}$ in 1978 to 3580000 kilometers in 2007, and the freeway length had broken through $50000 \mathrm{~km}$ over the past twenty years, it is therefore believed that the annual VMT for each vehicle category increased as well in China. Thus, the annual average VMT for each vehicle category in China was estimated for period of 1980-2005 based on Table 2, as shown in Table 3.

\subsubsection{Fossil fuel combustion}

The source of fossil fuel combustion contains various stationary combustion facilities that provide electricity and heat. The NMVOCs emissions from this source are determined by fuel types and combustion modes. Normally, burning gas and liquid fuel generate less NMVOCs emissions than burning
Table 4. NMVOCs emission factors for specific categories of stationary fossil fuel combustion in 2005 .

\begin{tabular}{llll}
\hline \multirow{2}{*}{ Sector } & Fuel type & \multicolumn{2}{c}{ Emission factor } \\
\cline { 3 - 4 } & & Value & Unit \\
\hline Thermal power generation & Coal & $0.15^{\mathrm{a}}$ & $\mathrm{kg} / \mathrm{ton}$ \\
& Fuel oil & 0.13 & $\mathrm{~kg} / \mathrm{ton}$ \\
& LPG & 66 & $\mathrm{~g} / \mathrm{m}^{3}$ \\
Heating & Natural gas & 0.18 & $\mathrm{~g} / \mathrm{m}^{3}$ \\
& Coal & $0.18^{\mathrm{a}}$ & $\mathrm{kg} / \mathrm{ton}$ \\
& Fuel oil & 0.19 & $\mathrm{~kg} / \mathrm{ton}$ \\
& LPG & 66 & $\mathrm{~g} / \mathrm{m}^{3}$ \\
Industrial and commercial consumption & Natural gas & 0.18 & $\mathrm{~g} / \mathrm{m}^{3}$ \\
& Coal & $0.18^{\mathrm{a}}$ & $\mathrm{kg} / \mathrm{ton}$ \\
& Fuel oil & 0.15 & $\mathrm{~kg} / \mathrm{ton}$ \\
& Coal gas & $0.00044^{\mathrm{a}}$ & $\mathrm{g} / \mathrm{m}^{3}$ \\
& LPG & 66 & $\mathrm{~g} / \mathrm{m}^{3}$ \\
Urban resident consumption & Natural gas & 0.18 & $\mathrm{~g} / \mathrm{m}^{3}$ \\
& Coal & $0.6^{\mathrm{a}}$ & $\mathrm{kg} / \mathrm{ton}$ \\
& Coal gas & $0.00044^{\mathrm{a}}$ & $\mathrm{g} / \mathrm{m}^{3}$ \\
& LPG & 66 & $\mathrm{~g} / \mathrm{m}^{3}$ \\
Rural resident consumption & Natural gas & 0.18 & $\mathrm{~g} / \mathrm{m}^{3}$ \\
& Coal & $0.6^{\mathrm{a}}$ & $\mathrm{kg} / \mathrm{ton}$ \\
& LPG & 66 & $\mathrm{~g} / \mathrm{m}^{3}$ \\
\hline
\end{tabular}

a experimental data obtained from Science Research Institute of Environmental Protection, Guang Zhou, 1998.

Others referred to AP42 report (1999).

solid fuel like coal because the combustion efficiency of solid fuel is lower and large combustion plants emit less NMVOCs than household boilers with much smaller tonnage when consuming the same amount of energy. Fossil fuel combustion source was divided into five subsources based on the different fuel types consumed: thermal power generation, heating, industrial and commercial consumption, urban resident consumption, and rural resident consumption. Table 4 presents the NMVOCs emission factors for specific fossil fuel categories in 2005, and the emission factors of these categories in other years were calculated by Eq. (2). Activity data of this source were collected from China Energy Statistical Yearbooks (1986-2006), China Rural Statistical Yearbooks (1985-2006) and provincial statistical yearbooks (1981-1984). 
Table 5. NMVOCs emission factors for specific categories of biomass burning.

\begin{tabular}{llll}
\hline Sector & Subsource & Emission factor & Unit \\
\hline \multirow{3}{*}{ biofuel } & cornstalk & $5.3^{\mathrm{a}}$ & $\mathrm{g} / \mathrm{kg}$ \\
& firewood & $5.3^{\mathrm{a}}$ & $\mathrm{g} / \mathrm{kg}$ \\
& biogas & $0.18^{\mathrm{a}}$ & $\mathrm{g} / \mathrm{m}^{3}$ \\
& & & \\
open burning & straw & $7.5^{\mathrm{b}}$ & $\mathrm{g} / \mathrm{kg}$ \\
& cornstalk & $10^{\mathrm{b}}$ & $\mathrm{g} / \mathrm{kg}$ \\
\hline
\end{tabular}

a values based on AP42 (1999).

b data are from native research (Li et al., 2007).

\subsubsection{Biomass burning}

The source of biomass burning contains biomass fuel including biogas, cornstalk and firewood, and open burning of agricultural waste. Two notable components of biomass burning are the incineration of wood, charcoal and agricultural waste as household fuel, and the combustion of crop residues in open fields (Yevich and Logan, 2003). Particularly, biofuel has been one of the major energy consumption types in China for a long time, especially in rural areas, where biofuel accounted for over $70 \%$ of the total energy consumption before 1979 (Cao et al., 2005).

Emission factors of China's biofuel burning were referred to AP42 due to information limitation, and the emission factors of biomass open burning were the locally measured data in China, as are listed in Table 5. Activity data of biofuel, including the consumption of biogas, cornstalk, and firewood as household fuel, were obtained from China Energy Statistical Yearbooks (1986-2006), China Rural Statistical Yearbooks (1985-2006), and provincial statistical yearbooks (1981-1984).

As for biomass open burning, the amount of crop residues in each province was calculated by Eq. (5).

$Q_{m}=Y_{k, m} \times R_{k} \times P_{m}$

where: $Q_{m}$ is the open burning amount of crop residues; $Y_{k, m}$ is the yield of crop $k$ in province $m$; $R_{k}$ is the production-toresidue ratio of crop $k$; and $P_{m}$ is the open burning proportion in province $m$.

Production-to-residue ratios and crop yields were shown in Table 6. In addition, provincial proportion of open burning of crop residues was calculated by combining information on regional climate, rural living standard, energy consumption modes, and control policies for open burning in each province.

\subsubsection{Storage and transport}

Volatilization and leakage of organic solvents during the storage and transport process, including distribution and
Table 6. Production-to-residue ratios and crop yields in China.

\begin{tabular}{lllll}
\hline \multirow{2}{*}{ Crop type } & \multirow{2}{*}{ Production-to-residue ratio $^{\mathrm{a}}$} & \multicolumn{3}{c}{${\text { Yield }(\mathrm{Tg} / \mathrm{yr})^{\mathrm{b}}}$} \\
\cline { 3 - 5 } & & 1995 & 2000 & 2005 \\
\hline paddy & 0.623 & 185.23 & 187.91 & 180.59 \\
wheat & 1.366 & 102.21 & 99.64 & 97.45 \\
corn & 2.0 & 111.99 & 106.00 & 139.37 \\
other grains & 1.0 & 16.70 & 11.68 & 10.37 \\
legume & 1.5 & 17.88 & 20.10 & 21.58 \\
potato & 0.5 & 32.63 & 36.85 & 34.69 \\
oil crops & 2.0 & 22.50 & 29.55 & 30.77 \\
cotton & 3.0 & 4.77 & 4.42 & 5.71 \\
hemp & 1.7 & 0.90 & 0.53 & 1.10 \\
sugarcane & 0.1 & 79.40 & 76.35 & 94.52 \\
\hline
\end{tabular}

adata from China Association of Rural Energy Industry, 2000.

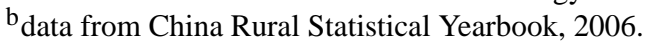

marketing of petroleum-derived products such as gasoline, crude oil and other volatile organic solvents used in daily life, is a potential source for NMVOCs emissions. Therefore, gasoline service stations and storage and transport of gasoline and crude oil were identified as sources for NMVOCs emissions in this study.

NMVOCs emissions from gas stations mainly involve with three aspects: liquid loading losses, tank breath losses, and vehicle refueling operation losses. In China, most gas stations adopted the way of immergence oil discharging and underground tanks, and had no control in the process of vehicle refueling. Therefore, the emission factors measured under the same situation in AP42 were selected, as shown in Table 7 .

Emission factors for gasoline and crude oil could be estimated by calculating their hydrocarbon dissipation coefficients, based on the approach introduced by Environmental Pollution Control during Oil Storage and Transport (Xia and Sun, 1992). The following hypotheses were assumed based on China's actual situation to estimate reasonable NMVOCs emission factors of oil and liquefied petroleum products during their storage: (1) raw materials and products were stored up only for one month; (2) only the evaporative emissions during the storage of crude oil and gasoline were considered, and evaporative emissions of light fuel oil were negligible; (3) evaporative emissions from the storage of heavy fuel oil and pressure storage for high volatile oil were negligible; (4) gasoline, crude oil and fuel oil were stored in floating roof tanks; (5) and densities of crude oil and gasoline from other oil fields were consistent with the oil standard implemented in Da Qing oil field. Estimated NMVOCs emission factors from storage evaporation for crude oil and gasoline were shown in Table 8.

The transport of petroleum liquids involved many distinct operations, each of which was a potential source of evaporation loss. For example, crude oil was transported from production plants to a refinery by tankers, barges, rail tank cars, tank trucks, or pipelines and refined petroleum products were 
Table 7. Suitable NMVOCs emission factors for China's gas stations selected from AP42.

\begin{tabular}{lll}
\hline \multirow{2}{*}{ Emission Source } & \multicolumn{2}{c}{ Emission Rate } \\
\cline { 2 - 3 } & $\mathrm{mg} / \mathrm{L}$ & $\mathrm{lb} / 10^{3}$ gal \\
& Throughput & Throughput \\
\hline $\begin{array}{l}\text { Filling underground tank } \\
\quad \text { submerged filling }\end{array}$ & 880 & 7.3 \\
$\begin{array}{l}\text { Underground tank breathing and emptying } \\
\text { Vehicle refueling operations }\end{array}$ & 120 & 1 \\
$\quad \begin{array}{l}\text { displacement losses (uncontrolled) } \\
\text { spillage }\end{array}$ & 1320 & 11 \\
& 80 & 0.7
\end{tabular}

Table 8. NMVOCs emission factors for storage of crude oil and gasoline.

\begin{tabular}{lllll}
\hline Type & $\begin{array}{l}\text { Density } \\
\left(\text { ton } / \mathrm{m}^{3}\right)\end{array}$ & $\begin{array}{l}\text { Dissipation coefficient } \\
\left(\mathrm{kg} / \mathrm{d} \mathrm{m}^{3}\right)\end{array}$ & \multicolumn{2}{c}{ Emission factors } \\
\cline { 4 - 5 } & $\mathrm{kg} / \mathrm{m}^{3}$ & $\mathrm{~kg} / \mathrm{ton}$ \\
\hline crude oil & 0.851 & 0.00348 & 0.1044 & 0.123 \\
gasoline & 0.760 & 0.00395 & 0.1185 & 0.156 \\
\hline
\end{tabular}

conveyed by tank trucks to service stations, commercial supply stations, and local bulk storage plants. Besides, fuel oils and other petroleum products had similar transport paths. By referring to the national standard of GB11085-89, the value of $1.6036 \mathrm{~g} / \mathrm{kg}$, the mean value of transport, loading and discharging losses, was adopted as the emission factor for oil transport.

Quantities of petroleum from transport and storage were unavailable from statistical data. Therefore, the aggregated quantities of petroleum from various processes, including importation, exportation, refinery, and vehicle refueling were estimated as the activity data. Particularly, provincial data from 1985 to 2005 were obtained from China Energy Statistical Yearbooks (1986-2006), while those in 1980 were estimated by allocating the national data in 1980 to the provincial level based on the provincial proportion in 1985 .

\subsubsection{Solvent utilization}

Solvent utilization, which had occupied approximately $25 \%$ of NMVOCs emissions per year in US from 1991 to 2006 (EPA, 2007), was one important source of anthropogenic NMVOCs emissions. Emission factors of this source in 2005 were selected from the 1995 data in AP42, due to the lack of appropriate emission factors in China, and the emission factors of this source in other years were estimated by Eq. (3). Major solvent categories and the corresponding emission factors in 2005 were shown in Table 9.

Activity data of this source, which mainly include population, production outputs, the number of plants and production lines of solvent, were obtained from China Market Yearbooks (1999-2006), China Light Industry Yearbooks 1949-1983 (1985), China Light Industry Yearbooks
Table 9. NMVOCs emission factors for solvent utilization.

\begin{tabular}{lll}
\hline Sector & $\begin{array}{l}\text { Emission } \\
\text { factor }\end{array}$ & $\mathrm{Units}$ \\
\hline Can coating & 100 & $\mathrm{Mg} / \mathrm{yr} /$ wire \\
Magnet wire coating & 84 & $\mathrm{Mg} / \mathrm{yr} /$ wire \\
Agriculture machines surface coating & 236 & $\mathrm{Mg} / \mathrm{yr} / \mathrm{plant}$ \\
Surface coating of plastic parts & 236 & $\mathrm{Mg} / \mathrm{yr} / \mathrm{plant}$ \\
for business machines & & \\
Metal furniture surface coating & 218 & $\mathrm{Mg} / \mathrm{yr} / \mathrm{plant}$ \\
Mucilage glue fiber & 50 & $\mathrm{Mg} / \mathrm{yr} / \mathrm{plant}$ \\
Typewriter & 60 & $\mathrm{Mg} / \mathrm{yr} / \mathrm{plant}$ \\
Other official res & 25 & $\mathrm{Mg} / \mathrm{yr} / \mathrm{plant}$ \\
Wood furniture & 0.4 & $\mathrm{~kg} / \mathrm{piece}$ \\
Machine tool equipment & 0.4 & $\mathrm{~kg} / \mathrm{piece}$ \\
Textile fabric printing & 81.4 & $\mathrm{~kg} / \mathrm{Mg}$ fabric \\
Automobile \& light duty truck & 21.2 & $\mathrm{~kg} / \mathrm{vehicle}$ \\
surface coating & & \\
Large appliance surface coating & 0.2 & $\mathrm{~kg} / \mathrm{production}$ \\
Bicycle surface coating & 0.3 & $\mathrm{~kg} / \mathrm{bike}$ \\
Architecture surface coating & $0.051^{*}$ & $\mathrm{~kg} / \mathrm{yr} / \mathrm{capita}$ \\
Automobile recoating & $0.021^{*}$ & $\mathrm{~kg} / \mathrm{yr} / \mathrm{capita}$ \\
Painting & $0.01^{*}$ & $\mathrm{~kg} / \mathrm{yr} / \mathrm{capita}$ \\
Dry cleaning & $0.02^{*}$ & $\mathrm{~kg} / \mathrm{yr} / \mathrm{capita}$ \\
Solvent degreasing & $0.044^{*}$ & $\mathrm{~kg} / \mathrm{yr} / \mathrm{capita}$ \\
Commercial/ Consumer solvent use & $0.1^{*}$ & $\mathrm{~kg} / \mathrm{yr} / \mathrm{capita}$ \\
\hline
\end{tabular}

Emission factors were selected from AP42 in Chapter 4 (EPA, 1995), and * emission factors per capita were calculated by multiplying conversion coefficient of 0.0246 , using per-capita income as proxy variable, based on the differences in living standards between China and the US.

(1985-2006), China Industrial Economic Statistical Yearbooks (1988-2006), and China Statistical Yearbooks (19812006) for the period of 1990-2005. Data in 1980 and 1985 were collected from provincial yearbooks of those years.

\subsubsection{Industrial processes}

Production processes of organic chemistry, inorganic chemistry, food, wood production and other industries are potential sources for NMVOCs emissions. Due to little information of NMVOCs emission factors of these industries in China, emission factors for these sources in 2005 were selected from AP42, based on the consideration upon the technical differences in these sources between China and US, as shown in Table 10. Activity data for these sources were referred to the same data sources as solvent utilization.

\section{Results and discussion}

\subsection{Emissions in 2005}

Total NMVOCs emissions in China was $16.5 \mathrm{Tg}$ in 2005 , including vehicles $5.5 \mathrm{Tg}$, biomass burning $3.8 \mathrm{Tg}$, industrial processes $2.8 \mathrm{Tg}$, fossil fuel combustion $2.0 \mathrm{Tg}$, solvent 
Table 10. NMVOCs emission factors for industrial processes.

\begin{tabular}{llll}
\hline Sector & $\begin{array}{l}\text { Emission } \\
\text { factors } \\
(\mathrm{g} / \mathrm{kg})\end{array}$ & Sector & $\begin{array}{l}\text { Emission } \\
\text { factors } \\
(\mathrm{g} / \mathrm{kg})\end{array}$ \\
\hline Synthetic fibre & 73.4 & $\begin{array}{l}\text { Ceramic clay } \\
\text { manufacturing }\end{array}$ & 0.003 \\
Synthetic rubber & 7.17 & $\begin{array}{l}\text { Portland cement } \\
\text { manufacturing }\end{array}$ & 0.177 \\
Plastic & 2.2 & $\begin{array}{l}\text { Bricks and related } \\
\text { clay products }\end{array}$ & 0.033 \\
Paint production & 15 & $\begin{array}{l}\text { Glass fiber } \\
\text { manufacturing }\end{array}$ & 3.15 \\
Synthetic ammonia & 4.72 & Coal cleaning & 0.2 \\
Vegetable oil & 2.45 & $\begin{array}{l}\text { Plywood } \\
\text { manufacturing }\end{array}$ & 0.5 \\
processing & & Pulp & 0.25 \\
Malt beverages & 0.74 & $\begin{array}{l}\text { manufacturing } \\
\text { Printing ink }\end{array}$ & 0.003 \\
Sugar processing & 0.6 & $\begin{array}{l}\text { Charcoal } \\
\text { manufacturing }\end{array}$ & 101 \\
\hline Coke production & 1.25 & &
\end{tabular}

Emission factors were selected from AP42 in Chapter 6-11 (EPA, 1995).

utilization $1.9 \mathrm{Tg}$, and storage and transport $0.5 \mathrm{Tg}$. The contribution of each source to the total emissions is shown in Fig. 1, which reveals that vehicles and biomass burning were the dominant sources on the national scale and contributed $33.3 \%$ and $23.3 \%$, respectively.

Detailed contribution of subsectors or subsources within the six main sources was shown in Fig. 2. Regarding vehicular emissions, motorcycles were the dominant subsource which occupied $49.8 \%$ of vehicular emissions in 2005 , due to their much larger population and high VMT. Why were motorcycles still the most influential subsource over the years, since many cities had restricted the development of motorcycles in urban area since the 1990s? There are two major reasons: one is that motorcycle population in rural areas increased fast with the rapid growth of economy and improvement of rural roads; the other is the tremendous transfer of motorcycles from cities to the vast countryside, which was stimulated by the absence of motorcycle restriction policies in the countryside, the low-grade rural roads and low price of motorcycles that forced choosing motorcycles to satisfy the need of goods and manpower transportation in rural areas. Therefore, the motorcycle pollution on the national scale was not well controlled but instead continued worsening. Heavy duty vans, whose population and VMT had rapidly increased

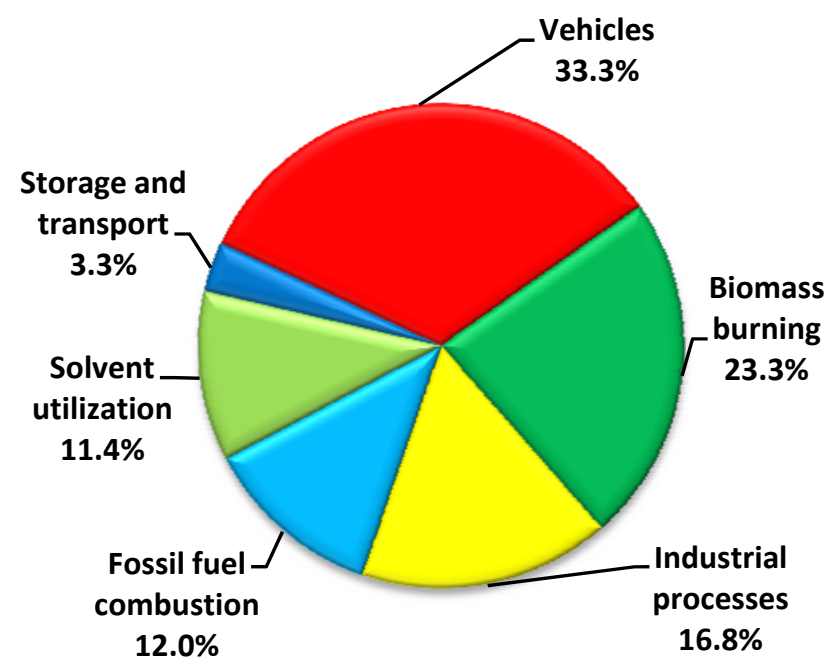

Fig. 1. Source contribution to the total emission in 2005.

with the fast economic growth, contributed $27.0 \%$ of the total vehicular NMVOCs emissions. In addition, passenger cars occupied $15.6 \%$ of vehicular emissions, followed by light duty vans and buses, which occupied $4.0 \%$ and $3.0 \%$, respectively.

With respect of biomass burning, biofuel (cornstalk, firewood, and biogas as household fuels) had occupied $76.3 \%$ of the total NMVOCs emissions of this source, and emission from cornstalk burning was twice more than that from firewood burning, due to the decreased amount of available firewood owing to the banning of hewing woods. Moreover, open burning contributed the remaining $23.7 \%$ of emissions, of which the burning of straw and cornstalk accounted for $13.2 \%$ and $10.5 \%$, respectively. The emission from biogas was only $0.0001 \mathrm{Tg}$, due to the low emission factor and the quite small consumption. Industrial and commercial consumption was the dominant subsource of NMVOCs emissions within the source of fossil fuel combustion, accounting for $43.3 \%$, due to the growing demand for fossil fuel stimulated by the rapid development of industrialisation. Another important contributor was urban consumption. Urban residents, occupying $43 \%$ of total Chinese population, were responsible for three times more emissions than rural residents in 2005, due to the huge consumption discrepancy between urban and rural areas, though emission factors for the fuel types adopted in cities were lower than those used in the countryside.

As for industrial processes, the subsectors of synthetic fibre, coke production, petroleum refining, and synthetic ammonia were the major contributors to the NMVOCs emissions, accounting for $39.9 \%, 11.5 \%, 10.1 \%$, and $7.9 \%$, respectively.

Regarding solvent utilization emissions, surface coating, especially that for agricultural machines and plastic parts of business machines, was the dominant subsource, due to its high emission factor and wide use. 


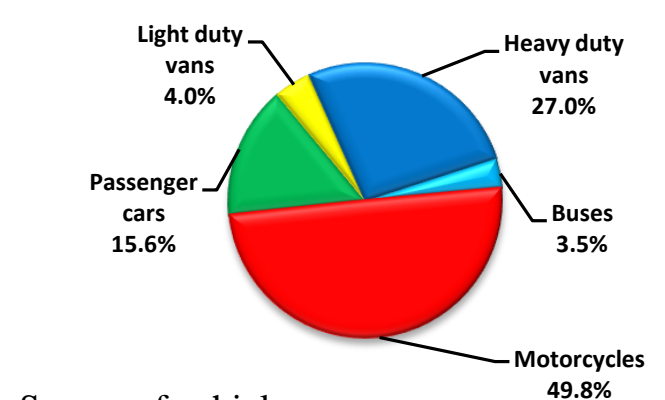

Source of vehicles

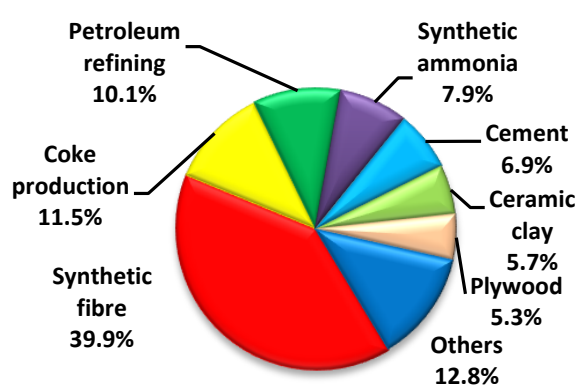

Source of industrial processes

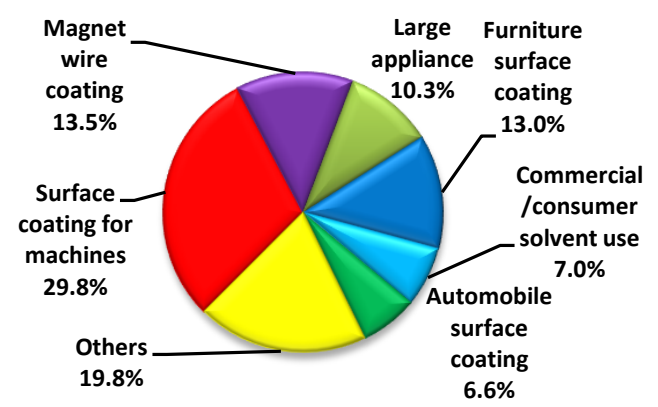

Source of solvent utilization

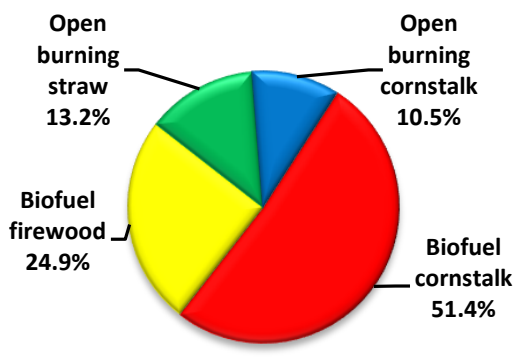

Source of biomass burning

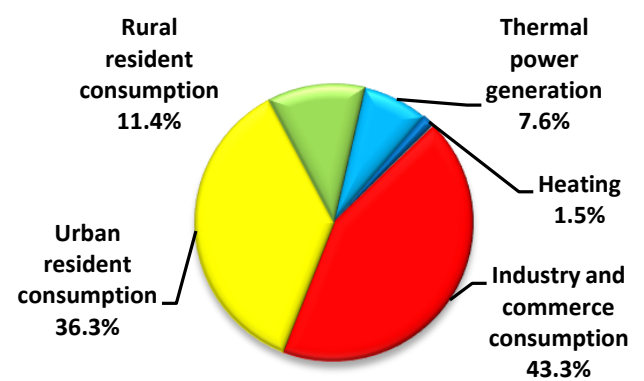

Source of fossil fuel combustion

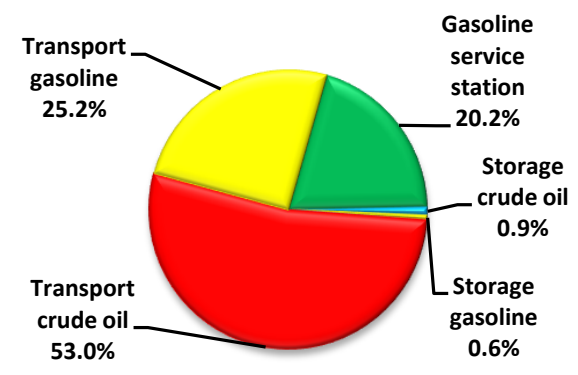

Source of storage and transport

Fig. 2. Subsector contributions within six major sources of NMVOCs emissions.

With respect of solvent storage and transport, transport contributed $78.2 \%$ of the total emissions, of which the tansport of crude oil and gasoline were the dominant subsectors, responsible for $53.0 \%$ and $25.2 \%$, respectively, much more than those from gasoline service stations and oil storage.

In sum, the major subsources for NMVOCs emissions in China in 2005 were motorcycles, biofuel burning, heavy duty vans, synthetic fibre production, biomass open burning, and industrial and commercial consumption, which accounted for $18.4 \%, 17.8 \%, 7.7 \%, 6.6 \%, 5.5 \%, 5.4 \%$ of the total emissions, respectively.

Provincial emissions and source contribution were depicted in Fig. 3, which shows that Guangdong was the province producing most NMVOCs emissions throughout China, with a total NMVOCs emission of $1.83 \mathrm{Tg}$ in 2005, which occupied $11.1 \%$ of the total emission in China, due to explosive increase of motorcycles, prosperous electric power generation, and booming industrial and commercial market. Simultaneously, provinces of Jiangsu, Zhejiang, and Shandong generated $1.46 \mathrm{Tg}, 1.27 \mathrm{Tg}$, and $1.12 \mathrm{Tg}$ of the emissions, respectively. These four provinces located in eastern coastal areas were all developed regions with high GDP, high population density and modern farming. On the contrary, Xizang, Qinghai, and Ningxia, three provinces located in the vast western inland areas with a sparse population and slow economic growth, generated only $0.03 \mathrm{Tg}, 0.05 \mathrm{Tg}$, and $0.09 \mathrm{Tg}$, respectively, in 2005 .

Source contributions of NMVOCs emissions at the provincial level were depicted in Fig. 4, to distinguish the local discrepancy of source contribution to NMVOCs emissions and find out the dominant sources responsible for local emissions. Figure 4 shows that the NMVOCs emissions in Shanghai were dominated by the source of fossil fuel combustion, which contributed $28.1 \%$, with the fossil fuel consumed by 


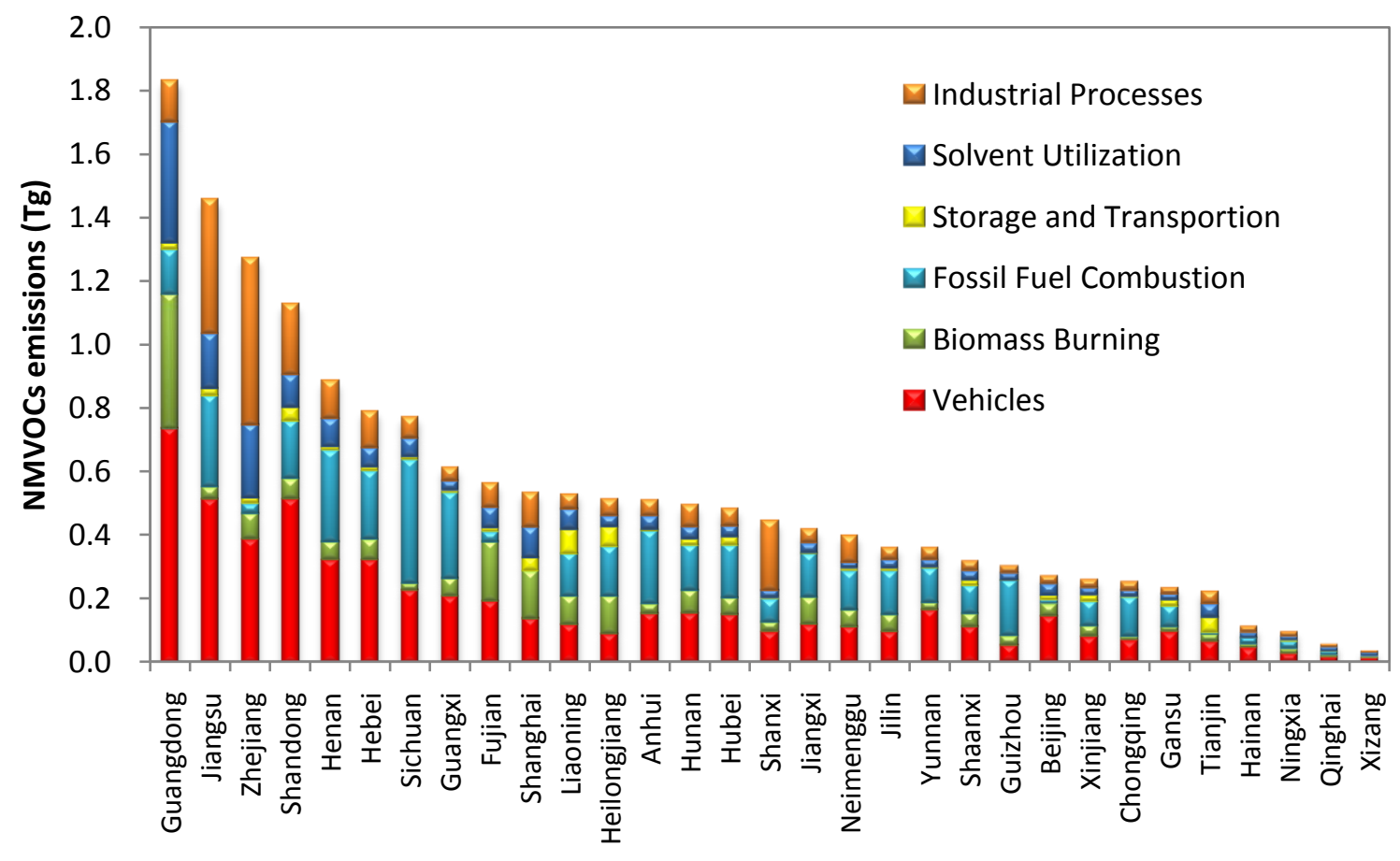

Province

Fig. 3. Anthropogenic NMVOCs emission inventory for each province in China (2005).

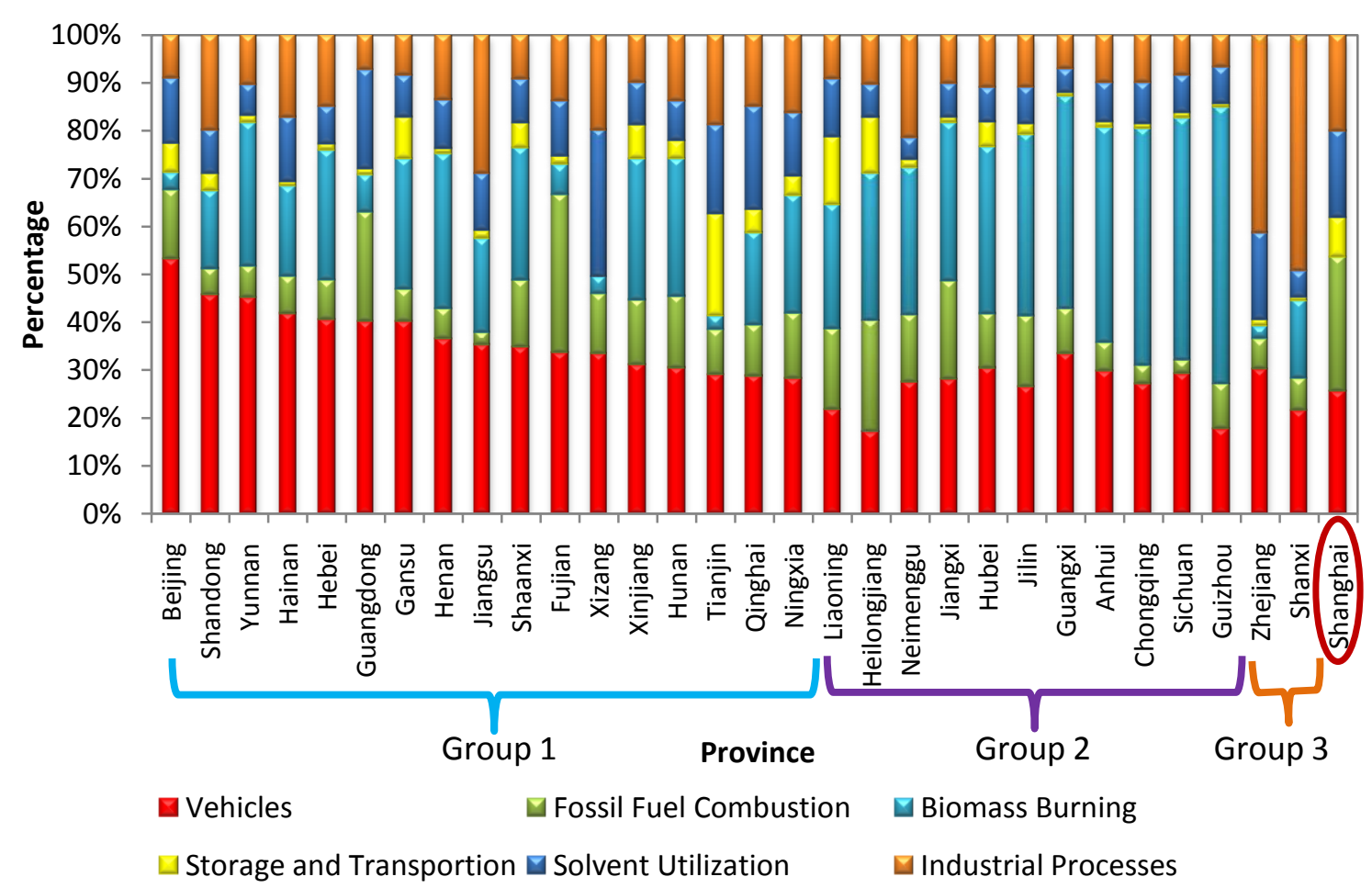

Fig. 4. Source contributions (vehicles, fossil fuel combustion, biomass burning, storage and transport, solvent utilization, and industrial processes) of NMVOCs emissions on the provincial scale in 2005. 
Table 11. Emissions of NMVOCs by source in China from 1980 to 2005 (Units: Gg).

\begin{tabular}{lrrrrrr}
\hline Source & 1980 & 1985 & 1990 & 1995 & 2000 & 2005 \\
\hline vehicles & 203 & 421 & 794 & 1923 & 3063 & 5497 \\
$\begin{array}{l}\text { fossil fuel } \\
\text { combustion }\end{array}$ & 340 & 362 & 614 & 841 & 1497 & 1979 \\
$\begin{array}{l}\text { biomass } \\
\text { burning }\end{array}$ & 1589 & 1483 & 1502 & 3815 & 3354 & 3837 \\
$\begin{array}{l}\text { storage and } \\
\text { transport }\end{array}$ & 237 & 278 & 299 & 319 & 389 & 546 \\
$\begin{array}{l}\text { solvent } \\
\text { utilization }\end{array}$ & 1093 & 1369 & 1307 & 1458 & 1362 & 1871 \\
$\begin{array}{l}\text { industrial } \\
\text { processes }\end{array}$ & 445 & 551 & 695 & 1049 & 1327 & 2761 \\
\begin{tabular}{l} 
total \\
\hline
\end{tabular} & 3907 & 4464 & 5211 & 9405 & 10992 & 16491 \\
\hline
\end{tabular}

industry and commerce accounting for $61.2 \%$ of the total fossil fuel combustion. The other thirty provinces could be classified into three groups according to the corresponding dominant source in each group. Group 1 consisting of seventeen provinces was dominated by vehicles as the primary contributing source; Group 2 consisting of eleven provinces was dominated by biomass burning as the primary contributing source; and Group 3 consisting of the provinces of Zhejiang and Shanxi was dominated by industrial processes as the primary contributing source, which accounted for $41.2 \%$ and $49.2 \%$ of the NMVOCs emissions in Zhejiang and Shanxi, respectively. Particularly, synthetic fibre and coke production were the major subsectors for the NMVOCs emissions in Zhejiang and Shanxi and were responsible for $92.8 \%$ and $69.8 \%$, respectively, of the total NMVOCs emissions from industrial processes. NMVOCs emissions in Beijing of Group 1 and Guizhou of Group 2 were close and were $0.27 \mathrm{Tg}$ and $0.30 \mathrm{Tg}$, respectively. However, the source contributions in these two provinces varied: vehicles accounted for $53.1 \%$ in Beijing, due to the large population of vehicles and frequent idle driving condition caused by traffic jams; On the other hand, biomass burning contributed $57.8 \%$ of emissions in Guizhou, an underdeveloped agricultural province in southwestern China, where crop residues and firewoods were widely used for domestic cooking by rural households and biomass open burning in the field often happened.

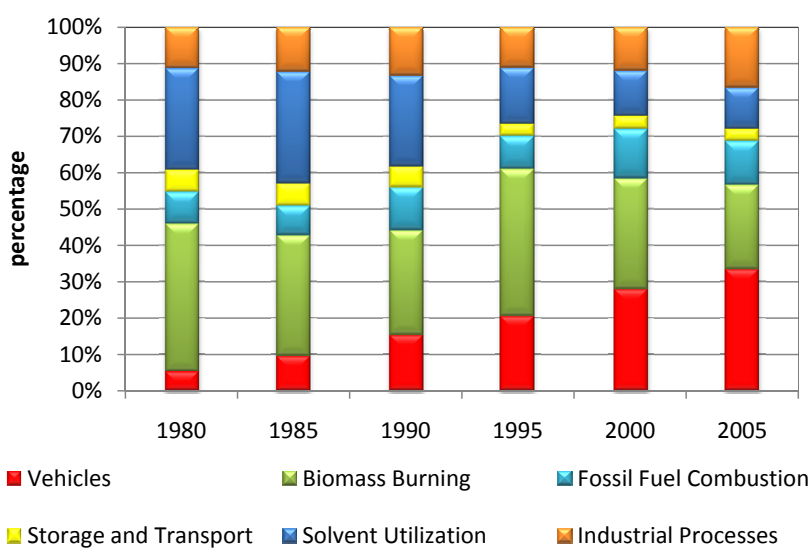

Fig. 5. Contribution of NMVOCs emissions from six sources during the period 1980-2005.

\subsection{Historical emissions from 1980 to 2005}

\subsubsection{Historical NMVOCs emissions}

Historical emissions were estimated for the period of 1980 to 2005, as shown in Table 11, which reveals that China's NMVOCs emissions had increased by 4.2 times at an annual average rate of $10.6 \%$ from $3.91 \mathrm{Tg}$ in 1980 to $16.5 \mathrm{Tg}$ in 2005. Emissions from vehicles, industrial processes, fossil fuel combustion, biomass burning, storage and transport, and solvent utilization had grown by $27,6.2,6.0,2.4,2.3$, and 1.7 times, respectively. A sharp increase of emissions occurred during the period of 1990-1995, with the emission almost doubling from 5.2 Tg in 1990 to $9.4 \mathrm{Tg}$ in 1995. Meanwhile, emissions of vehicles and biomass burning had increased by 2.4 and 2.5 times, respectively, the major reasons of which were the rapid growth of vehicle population which had doubled during the period, and the popular practice of open burning of crop residues in the field since the early 1990s which accounted for 25\% of NMVOCs emissions in 1995.

Table 11 also shows that the NMVOCs emissions from the six sources in China during the period of 1980-2005 increased at different degree, and the contribution of these sources in each year was depicted by Fig. 5, which shows that the contribution of vehicles had increased from $5.2 \%$ in 1980 to $33.3 \%$ in 2005 at a steady and rapid rate, and had become the dominant contributor to NMVOCs emissions, due to the substantial growth of vehicle population in China which had increased by 60 times from 1.8 million to 107 million during the period (China Automobile Industry Association, 2006). As the biggest developing country, China had 57\% rural population in 2005 (NBS, 2006), and it had a long history of using agricultural waste and firewood to satisfy energy demand. Thus, biomass burning had been the largest emission source before 2005, especially in the year 1980 and 1995 , when it occupied $40.7 \%$ and $40.6 \%$ of the total emission, respectively. It accounted for $23.3 \%$ of the 


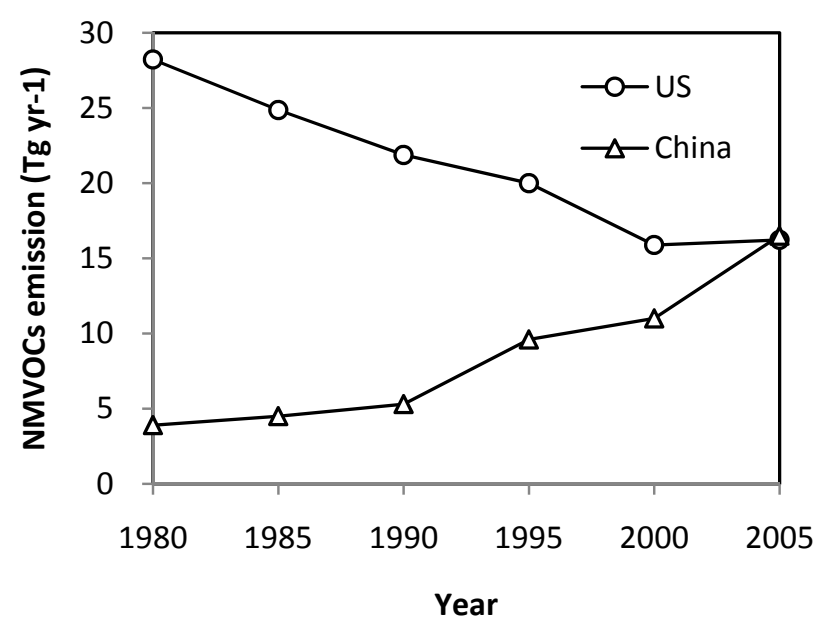

Fig. 6. Comparison of annual NMVOCs emissions in the US and China.

total emission in 2005, showing a decreasing trend of contribution, though Table 11 reveals that the emission of this source continued to increase. Meanwhile, the utilization of different types of biomass changed over the years. Firewood and agricultural waste, which were widely used as household fuel in low-income households that lacked consumption capacity for commercial fuel, were the largest NMVOCs emission subsources in 1980. Biomass was open burned in the field as farming residues in the early 1990s when the economic condition in rural China improved. Thus, open burning of biomass became the major subsource of NMVOCs emissions thereafter. The NMVOCs emissions from fossil fuel combustion increased year by year, and the contribution of this source rose from $8.7 \%$ in 1980 to $12.0 \%$ in 2005 . The source of industrial processes had the same annual variation trend with the source of fossil fuel combustion, and its contribution to the total emission increased from $11.3 \%$ in 1980 to $16.7 \%$ in 2005 . These phenomena revealed that both energy consumption and industrialization in China in the past twenty-five years were experiencing rapid growth. Though the emissions of the sources of storage and transport and solvent utilization also had an increasing trend, their increasing rates were relatively slower than other sources. Therefore, their contributions to the total emission had been decreasing year by year from $6.6 \%$ and $28.0 \%$, respectively, in 1980 to $3.3 \%$ and $11.4 \%$, respectively, in 2005 .

Figure 6 compares the historical NMVOCs emissions bewteen China and the US. It is shown that the NMVOCs emissions in the US was over ten times more than that in China in 1980. However, NMVOCs emissions grew rapidly in China and had exceeded those in the US in 2005. Transportation had been the dominant source of NMVOCs emissions in the US, but the vehicular NMVOCs emissions there had decreased from $12.6 \mathrm{Tg}$ in 1980 to $3.68 \mathrm{Tg}$ in 2005 , due to the decreased evaporation of motorcycle fuel, which

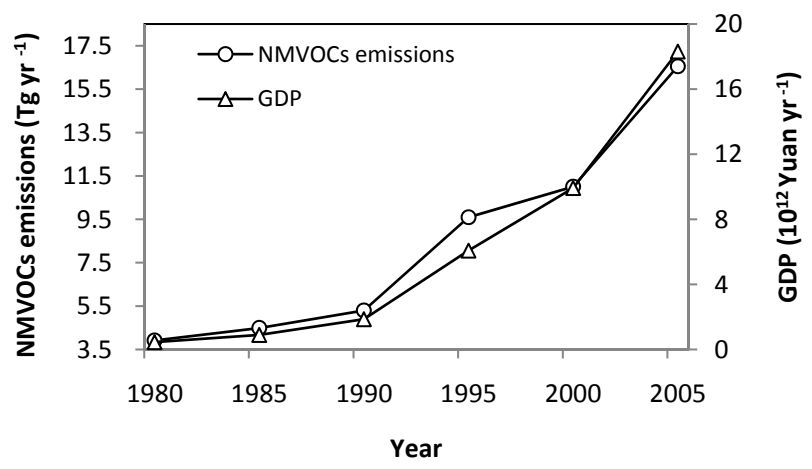

Fig. 7. Developing trends of Chinese historical NMVOCs emissions and GDP.

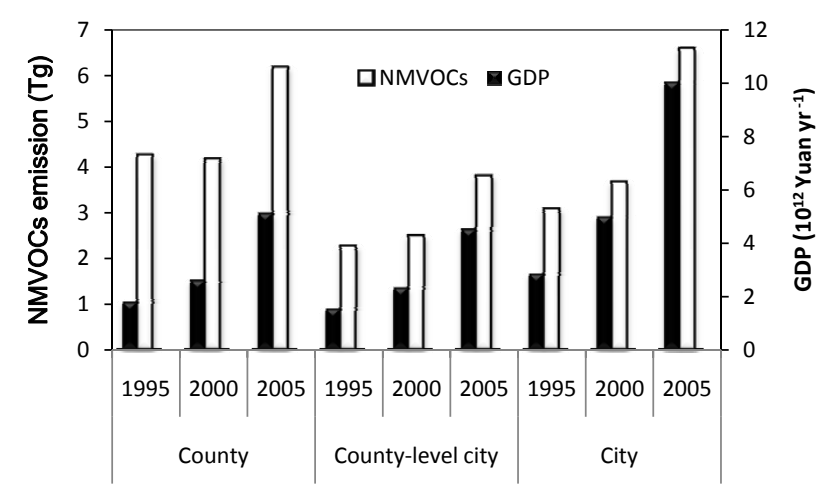

Fig. 8. Variations of NMVOCs emissions and GDP for different administration regions from 1995 to 2005 .

brought about the rapid decrease of the total NMVOCs emissions since 1989 (Cilek and Kohout, 1992). Hence, the successful experience in the US is definitely valuable for controlling the vehicular NMVOCs emissions in China.

\subsubsection{Relationship between NMVOCs emissions and the economy in China}

To find out the pivotal factors causing continuous growth of NMVOCs emissions, demographic, socio-economic, and geoponic statistical data were widely investigated. Statistical results showed that the NMVOCs emissions and GDP were well positively correlated, with a correlation coefficient of 0.99, as illustrated in Fig. 7, which demonstrated that economic growth had promoted the rapid increase of anthropogenic NMVOCs emissions in China.

The NMVOCs emissions and GDP of counties, county level cities, and cities, three types of administration regions with diverse levels of population and economic development, were presented in Fig. 8 to further investigate the influence of different economic development levels on the correponding NMVOCs emissions. Figure 8 reveals that NMVOCs emissions in counties, county level cities, and cities went up with 

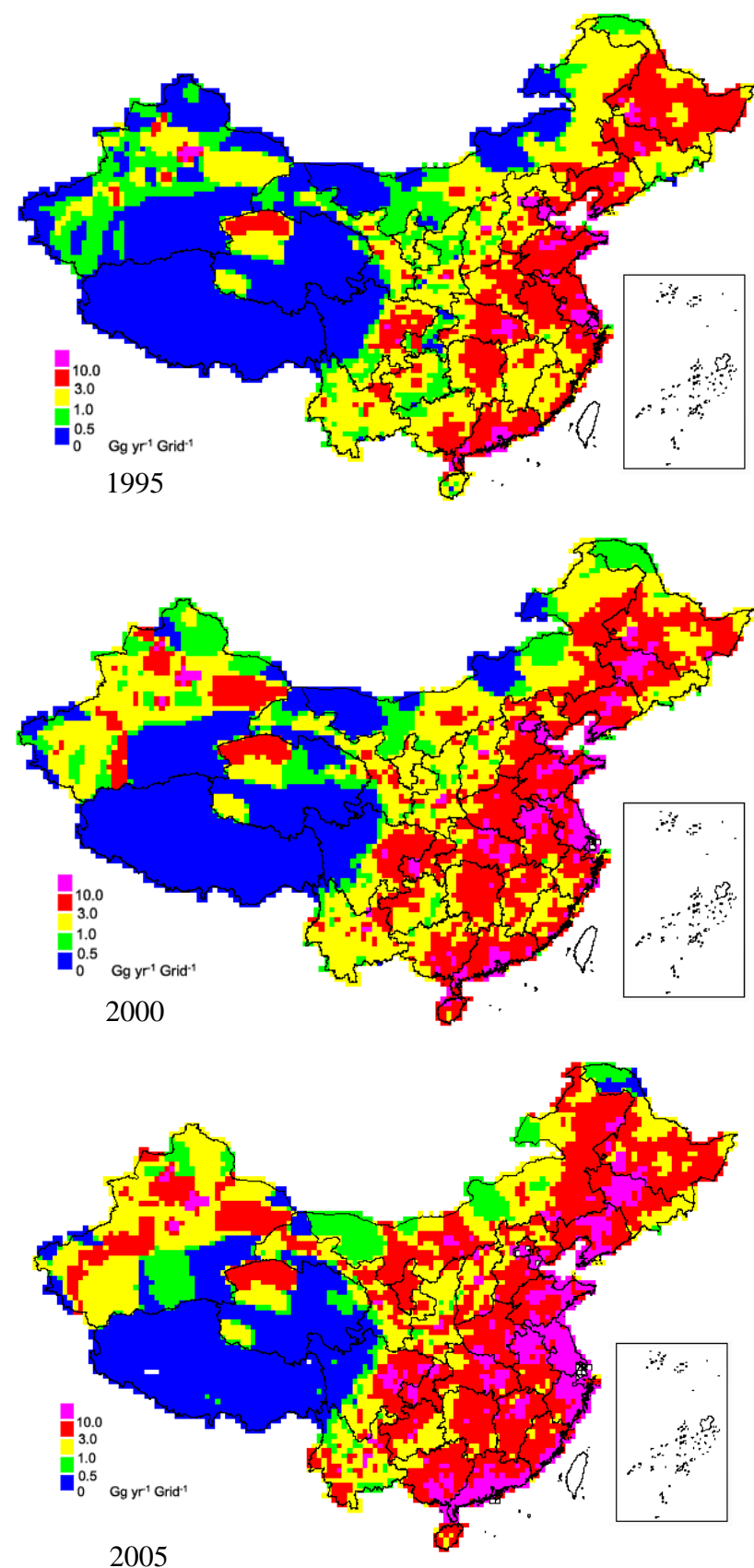

Fig. 9. The spatial distribution of NMVOCs emissions in 1995, 2000 , and 2005 at a high resolution of $40 \mathrm{~km} \times 40 \mathrm{~km}$.

the corresponding growth of GDP there, and the NMVOCs emissions per unit of GDP in county areas were significantly higher than those in county level cities and cities. In 2005, counties produced about $50.9 \%$ of the GDP in cities, but NMVOCs emissions in counties was $6.2 \mathrm{Tg}$, close to the $6.6 \mathrm{Tg}$ generated by cities. This was mainly because many small-scale and pollution-heavy plants were transferred from cities where more and more stringent environmental management policies were implemented to the underdeveloped rural areas with loose environmental management. Furthermore, the low economic development level in most rural areas led to the widespread of low-efficient utilization of biofuel in those areas, like biomass burning, which also caused the high NMVOCs emissions per unit of GDP in rural areas. Thus, the way of pollution-heavy and energy-intensive development in counties should be improved to reduce the increasing NMVOCs emissions in China's county areas.

\subsection{Spatial distribution of anthropogenic NMVOCs emis- sions in China}

To recognize the temporal and spatial variation characteristics of the anthropogenic NMVOCs emissions in China, the NMVOCs emission inventories at a high resolution of $40 \mathrm{~km} \times 40 \mathrm{~km}$ were established using the GIS methodology, as depicted in Fig. 9, which shows the spatial distribution of NMVOCs emissions in 1995, 2000, 2005. Figure 9 reveals that one notable characteristic of the spatial distribution of China's NMVOCs emissions is that the NMVOCs emissions were much higher in eastern China than in western China, and the coastal regions had been zoned as most polluted areas of NMVOCs. Moreover, the northern coastal region, eastern coastal region, southern coastal region, the three provinces in northeastern China and the Sichuan Basin were typical highemission regions, and particularly, the Yangtze River Delta, the Pearl River Delta, and the circumjacent areas of Beijing stood out with highest emissions. This characteristic of spatial distribution was closely related with the unbalanced economic development in China, and it was obvious that various areas of China had tremendous differences in NMVOCs emissions, with the annual NMVOCs emissions at county level ranging from $462 \mathrm{Gg}$ in the urban district of Shanghai to $0.025 \mathrm{Gg}$ in Cuona county of Xizang Autonomous District. Another distinguished emission characteristic was that the NMVOCs emissions mainly peaked over the large urban areas, and these high emission regions began to scatter around the domain, resulting in the expansion of high emission regions during the period of 1995-2005. In addition, extraordinaryly high emissions mainly concentrated in southeastern, northern, and central regions, which altogether cover $35.2 \%$ of China's territory, but generated $59.4 \%$ of the total emissions. On the contrary, the western provinces of Xizang, Shaanxi, Gansu, Qinghai, Ningxia, and Xinjiang, which altogether cover $44.6 \%$ of the territory, contributed only $5.8 \%$ of the total emissions. Besides, the capital cities of China, which cover merely $4.5 \%$ of China's territory, were responsible for $24.9 \%$ of the national emissions of NMVOCs in 2005. Figure 9 also illustrates that the spatial distribution in 1995 and 2000 was similar with that in 2005 , but the emission intensity of high emission regions had been increasing and the area of these regions had been expansive over the years, showing an expanding trend of emissions from eastern and southern China to northwestern China.

To discern the characteristics of the temporal and spatial 
distribution of emissions from each source, the spatial distributions of the emissions from the six sources were illustrated at a high resolution of $40 \mathrm{~km} \times 40 \mathrm{~km}$ for 1995,2000 and 2005, respectively, as shown in Fig. 10.

The spatial distribution of the NMVOCs emissions from vehicles in 1995, 2000 and 2005 was shown by Fig. 10a, which reveals that vehicular NMVOCs emissions in China presented a clear characteristic of regional distribution, with the emission intensity increasing from northwestern inland regions to southeastern coastal areas. Regions with high emission intensity showed an expansive trend from southeastern coastal areas to northwestern inland regions. Besides, regions with high emissions mainly concentrated in cities, which was in accordance with the fact that vehicles in China concentrated in cities and dovetailed with the disproportional development of freeway construction: till 1998, $59.7 \%$ of freeway was built in the east, and $26.9 \%$ of freeway was constructed in the middle, with the remaining $13.4 \%$ lying in the west ( $\mathrm{Li}$ et al., 2000). Moreover, the expansion of NMVOCs emissions from east to west accompanied China's West Region Development commencing in 2000. The cities of Guangzhou, Shanghai, Beijing, and Shenzhen were the dominant emission contributors. As for Guangdong, the province generating most NMVOCs emissions throughout the country, the popular use of motorcycles there was the fundamental cause, which suggested that the emission standards of motorcycles should be improved and the use of motorcycles should be put under stringent control, in the perspective of controlling NMVOCs emissions.

The spatial distribution of the NMVOCs emissions from biomass burning in 1995, 2000 and 2005 was shown by Fig. 10b, which illustrates that emission from biomass burning concentrated in Heilongjiang, Liaoning and Jilin, the three northeastern provinces; in Jiangsu, Zhejiang and Fujian, three southeastern provinces; in the southern provinces of Guangdong and Guangxi; in the eastern and central provinces of Anhui, Jiangxi, Hebei, Henan, Shandong, Hubei and Hunan; and in southwestern provinces of Sichuan, Yunnan, Guizhou and Chongqing. These provinces generated as much as $87.2 \%$ of the total NMVOCs emissions in China, and the emission intensity in these areas showed an increasing trend. In the northeast, where crop residues were used for cooking and heating, a great deal of cornstalk and straw could be obtained and burned as free fuel to substitute for part of the commercial fuel to get through the cold winter. Another region responsible for enormous emission from biomass open burning was southern China, especially in Jiangsu, Hubei, and the typical agricultural province of Anhui, where open fire spots in harvest season had been discovered several times in recent years (National Satellite Meteorological Center, 2005).

The spatial distribution of the NMVOCs emissions from industrial processes in 1995, 2000 and 2005 was shown by Fig. 10c, which shows that the areas with high NMVOCs emissions mainly concentrated in Shandong, Beijing, the
Yangtze River Delta, and the Pearl River Delta in 1995, where plenty of large-scale industrial plants were built. After ten years' industrialization, the regional distribution of NMVOCs emissions from this source changed substantially, with the former high emission areas continuing expanding and the emission intensity in central and northeast regions increasing significantly. Particularly, 52.3\% of the NMVOCs emissions from industrial sources were produced in eastern China, where the gross industrial output increased steadily from $63 \%$ in 1995 to $69 \%$ in 2005.

The spatial distribution of the NMVOCs emissions from fossil fuel combustion in 1995, 2000 and 2005 was shown by Fig. 10d, which shows a clear characteristic of regional distribution: in 1995, high emission areas mainly concentrated in the Yangtze River Delta, the Pearl River Delta, and the Circum-Bohai-Sea Region and the emission intensity of these high emission areas continued to increase thereafter, showing an expansive trend of emission from southeastern coastal and southern areas to central, northwestern and northeastern regions.

The spatial distribution of the NMVOCs emissions from solvent utilization in 1995, 2000 and 2005 was shown by Fig. 10e, which illustrates that the emission in 1995 from solvent utilization mainly concentrated in the Pearl River Delta, the Yangtze River Delta, and the circumjacent areas of Beijing, where the production of coating material accounted for $60 \%$ of the total. However, thousands of small-scale plants outspread to small towns lack of strict environmental management, which caused the transfer of pollutant from cities to the countryside, as shown in Fig. 10e. Thus, the high emission areas continued to expand thereafter, showing an expansive trend of emissions in northeastern, southeastern, and central China.

The spatial distribution of the NMVOCs emissions from storage and transport in 1995, 2000 and 2005 was shown by Fig. 10f, which illustrates that areas with high NMVOCs emissions from storage and transport mainly distributed around megalopolis and several huge oil fields of China, such as Daqing, Shengli, Liaohe, Zhongyuan, and Kelamayi, due to the huge amount of transport of crude oil around the fields. Besides, the NMVOCs emissions in the Pearl River Delta, the Yangtze River Delta and the circumjacent areas of Beijing were mainly ascribed to the large quantities of the consumption of oil and petroleum products. Therefore, it is foreseeable that the emission intensity of NMVOCs in northwestern China would continue to increase, with the further exploit of huge oil fields like Kelamayi.

3.4 Comparison of China's NMVOCs emission inventories estimated by different scholars and the uncertainty analysis

Results about China's NMVOCs emissions firstly appeared in the global NMVOCs emissions estimated by Piccot et al. (1992), followed by the research relevant with China's 

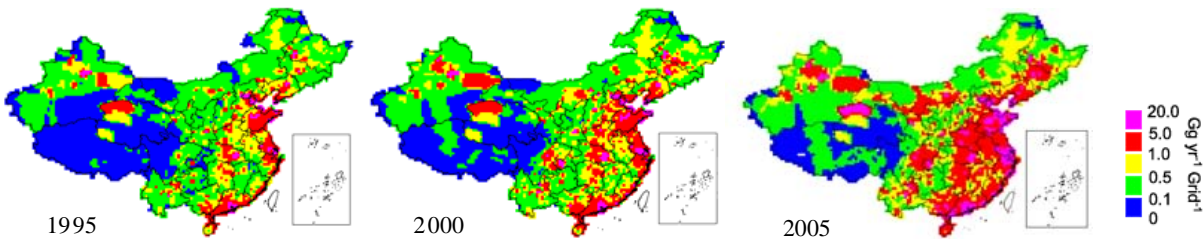

(a)
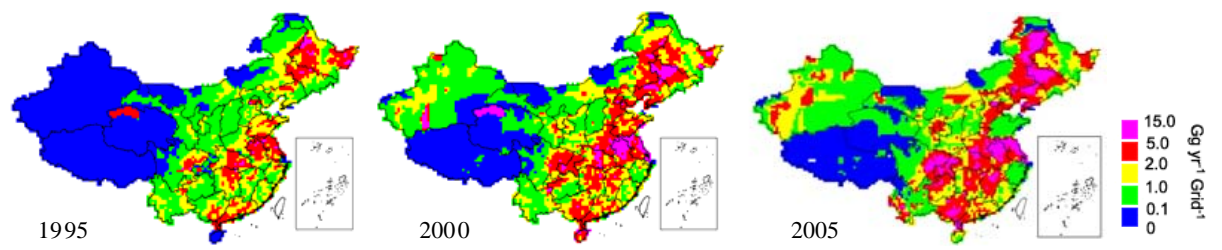

(b)
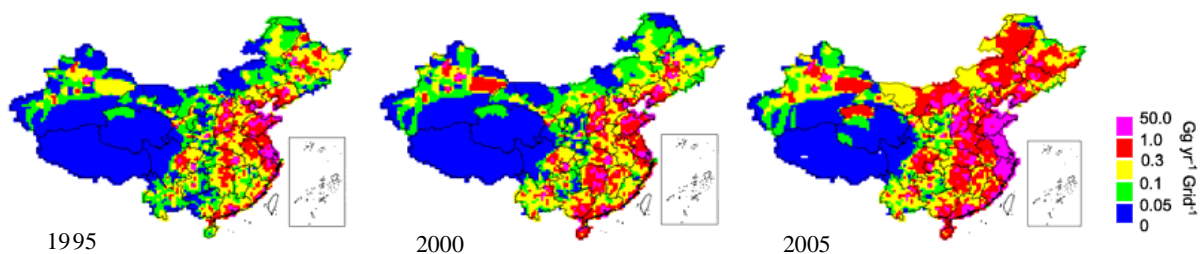

(c)
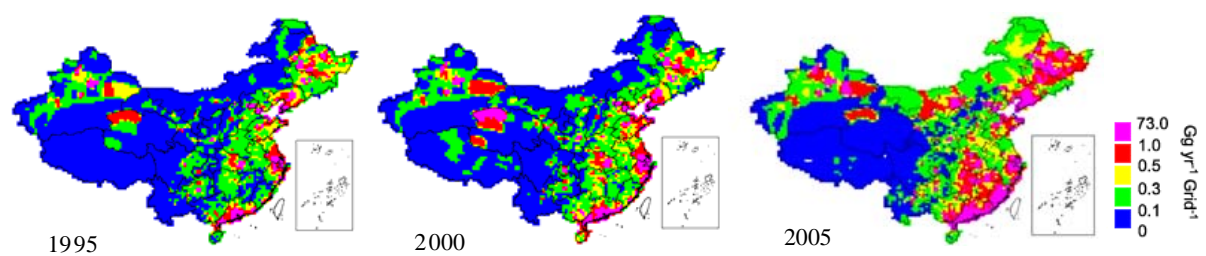

(d)
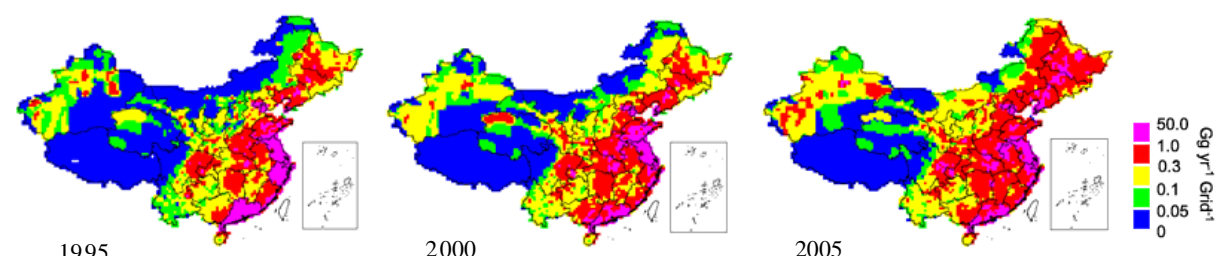

(e)
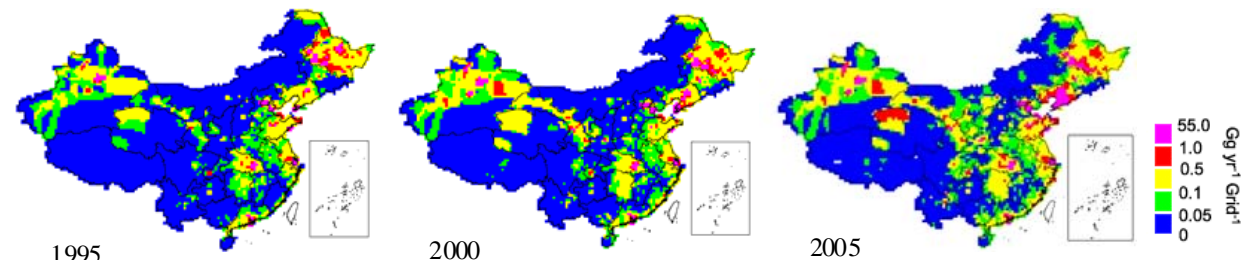

(f)

Fig. 10. Annual changes in spatial distribution of NMVOCs emissions at a high resolution of $40 \mathrm{~km} \times 40 \mathrm{~km}$ for (a) vehicles, (b) biomass burning, (c) industrial processes, (d) fossil fuel combustion, (e) solvent utilization, and (f) storage and transport, in 1995, 2000, and 2005, based on GIS methodology. 
Table 12. Comparison of China's NMVOCs emission inventories (Unit: $\operatorname{Tg~yr}^{-1}$ ).

\begin{tabular}{lllllllll}
\hline NMVOCs emissions & 1980 & 1985 & 1990 & 1995 & 2000 & 2005 & 2010 & 2020 \\
\hline Piccot et al. (1992) & & 5.3 & & & & & & \\
Olivier et al. (1996, 2001/2002) & & & $18.2^{\mathrm{a}}$ & $13.7^{\mathrm{b}}$ & & & & \\
Tonooka et al. (2001) & & & & 13.8 & & & & \\
Klimont et al. (2002) & & & 11.1 & 13.1 & 15.6 & & 17.2 & 18.2 \\
Streets et al. (2003) & 6.8 & 8.2 & 9.7 & 12.2 & 17.4 & & & \\
Ohara et al. (2007) & 3.9 & 4.5 & 5.2 & 9.6 & 11.0 & $17.2^{\mathrm{c}}$ & & \\
In this study & & & & & & &
\end{tabular}

a studied domain contained the regions of China, Hong Kong, Cambodia, North Korea, Laos, Macau, Mongolia, and Vietnam in total.

${ }^{b}$ studied domain included the regions of China mainland, Hong Kong, Macao, Taiwan, Mongolia, North Korea, South Korea, and Guam in total.

c emission estimated for 2003.

NMVOCs emissions conducted by Olivier et al. (1996, 2001/2002), Tonooka et al. (2001), and Klimont et al. (2002). Recently, Streets et al. (2003) and Ohara et al. (2007) have estimated the NMVOCs emissions in China. Therefore, we compared the results of above scholars with our estimation, as shown in Table 12.

Table 12 shows that Piccot's result in 1985 was $5.3 \mathrm{Tg}$, which was a little more than our estimation of $4.5 \mathrm{Tg}$ in the same year. China's emission of $18.2 \mathrm{Tg}$ in 1990 estimated by Olivier et al. (1996) covered the territories of China, Hong Kong, Cambodia, North Korea, Laos, Macau, Mongolia, and Vietnam, and the East Asian emission of $13.7 \mathrm{Tg}$ in 1995 estimated by Olivier et al. (2001/2002) covered the territories of the Chinese mainland, Hong Kong, Macao, Taiwan, Mongolia, North Korea, South Korea, and Guam. They were both higher than the emissions estimated in this study in the corresponding years, which were $5.2 \mathrm{Tg}$ in 1990 and $9.4 \mathrm{Tg}$ in 1995, respectively. In Tonooka's emission inventory for 1995, coal combustion was the largest source occupying approximately $40 \%$ of the total NMVOCs emissions based on the emission factors for boilers of diverse sizes, while our results showed that biomass burning was still the dominant emission source in 1995. Klimont et al. (2002) estimated the emissions in China for the years 1990, 1995 and 2000, based on which Streets et al. (2003) obtained an estimation of $17.4 \mathrm{Tg}$ for China in 2000 by further calculating the NMVOCs emissions from forest and praipie fires which accounted for $1.8 \mathrm{Tg}$ in 2000. In addition, the NMVOCs emissions for 1995 and 2000 in the REAS inventory established by Ohara et al. (2007) were not estimated independently, but instead came from the results of Klimont et al. (2002) and Streets et al. (2003). Moreover, their NMVOC emissions for the period 1980-2003 were estimated simply by an extrapolation of the NMVOC emissions for 1995 and 2000, using a proxy indicator per sector. Therefore, we focused on comparing our estimation with the results by Klimont et al. (2002). Table 12 shows that there was notable discrep- ancy in the amount of NMVOCs emissions, especially for the year 1990, when the estimation by Klimont et al. (2002) was about 2.1 times more than ours. This emission discrepancy was mainly ascribed to the differences in the selection of emission factors and activity data for the corresponding anthropogenic sources of NMVOCs emissions.

Upon comparison of the activity data adopted by Klimont et al. (2002) and in this study, as shown in Table 13, we found that activity data used by Klimont et al. (2002) were all higher than those adopted in this study, except those for production and consumption of oil and gas. Our activity data were mainly from China Energy Statistical Yearbook (2005); China Automotive Industry Yearbook (2002); China Marketing Yearbook (2001); and China Forestry Statistical Yearbook (2006). Their activity data in 2000 were mainly estimated based on China's energy statistical data in the former years and related data of energy consumption in the US, because the relevant data in 2000 had not been released yet when Klimont et al. (2002) established the NMVOCs emission inventory of China in 2000. Therefore, our activity data based on China's statistical yearbook differred from those adopted by Klimont et al. (2002). For example, coal consumption, biofuel and other energy consumption, paint production, paint use, and industrial wood production were $1.22,4.19,6.77,6.22$ and 5.05 times more than our respective sources. Hence, our estimation of China's NMVOCs emission inventory in 2000 was less than that estimated by Klimont et al. (2002).

Another important factor influencing the result was the emission factor. Emission factors adopted in this study were slightly lower than those used by Klimont et al. (2002). For example, the vehicular emission in 2000 calculated by Klimont et al. (2002) was $5071 \mathrm{Gg}$, which was much higher than our estimation of $3063 \mathrm{Gg}$. This was not only because their activity data were larger than ours, as shown in Table 13, but also because their adopted emission factors for vehicles were slightly higher than ours. The emission factors adopted 
Table 13. Comparison of activity data for each sector between Klimont's research and this study.

\begin{tabular}{llll}
\hline Sector & Unit & $\begin{array}{l}\text { Klimont } \\
\text { et al. (2002) }\end{array}$ & $\begin{array}{l}\text { This } \\
\text { study }\end{array}$ \\
\hline $\begin{array}{l}\text { Domestic oil production } \\
\begin{array}{l}\text { Domestic gas production } \\
\text { Energy consumption }\end{array}\end{array}$ & $10^{6}$ tons & 150 & $180^{\mathrm{a}}$ \\
Coal & & 18 & $40878^{\mathrm{a}}$ \\
Oil & PJ & 33532 & $27532^{\mathrm{a}}$ \\
Gas & PJ & 8655 & $9333^{\mathrm{a}}$ \\
Hydro & PJ & 1959 & $2839^{\mathrm{a}}$ \\
Nuclear & PJ & 1742 & $801^{\mathrm{a}}$ \\
Other (includes biofuel) & PJ & 147 & $60^{\mathrm{a}}$ \\
Vehicle manufacturing & $10^{6}$ vehicles & 8550 & $2725^{\mathrm{a}}$ \\
Paint production & $10^{3}$ tons paint & 2417 & $2.1^{\mathrm{b}}$ \\
Paint use & $10^{3}$ tons paint & 2735 & $447^{\mathrm{c}}$ \\
Industrial wood & $10^{6} \mathrm{~m}^{3}$ & 101 & $20^{\mathrm{d}}$ \\
\hline
\end{tabular}

a: China Energy Statistical Yearbook, 2005; b: China Automotive Industry Yearbook, 2002; c: China Market Yearbook, 2001; and d: China Forestry Statistical Yearbook, 2006.

by Klimont et al. (2002) to estimate China's transport source emissions in 2000 were based on the European experience of the mid-1980s. However, emission standards equivalent to Europe I have come into effect in China since 2000. Therefore, it was not quite suitable to calculate China's emission in 2000 by using emission factors based on the European experience of the mid-1980s. Considering the introduction and execution of stricter vehicle emission standards and distinct policies and statutes in different times, we calculated China's region-specific and year-specific NMVOCs emission factors for vehicles, using COPERT III model which was reliably applicable in China, because the COPERT III results were closer to the measured emission factors by platform experiments than the MOBILE results, especially for the gasoline vehicles (Xie et al., 2006). Therefore, it accords better with China's actual situation to calculate the emission factors using COPERT III. Moreover, for some vehicle types, emission factors calculated by MOBILE are higher than those calculated by COPERT III, and this is why some Chinese vehicular NMVOCs emissions calculated by MOBILE models were higher than our results.

As described above, activity data of each source obtained from available and credible published statistical yearbooks and the emission factors adopted in this study were both lower than those compiled by Klimont et al. (2002), Streets et al. (2003), Ohara et al. (2007), Olivier et al. (2001, 2002) and Tonooka et al. (2001), which resulted in a lower estimation in this study than above studies.

Emission inventories estimated by different scholars differred significantly, and the uncertainty of the inventories derives from the use of different emission factors and activity data. Most of the emission factors in this study were selected from AP42 and literatures, due to the lack of locally measured data, which to some extent caused the uncertainty of the estimated NMVOCs inventory in China. Therefore, we conducted the uncertainty analysis for the emission factors and activity data, according to the USEPA's recommended methodology for uncertainty analysis (EPA, 2007).

When conducting the uncertainty analysis, the emission factors and activity data to be used as sample data for the uncertainty analysis were firstly selected, and the probability density function (PDF) the sample data fit best was determined based on the Moran's statistic, followed by the calculation of the statistics of the mean value and the standard deviation of the determined PDF, using maximum likelihood estimation. Based on the above procedures, the sample data of the emission factors from each subsource of the six sources, as well as the activity data were selected, and the PDF they fit best was determined. Then, the Monte Carlo simulation was repeatedly implemented with new input values randomly selected from within the respective probability distribution of the emission factors and activity data of each source. For each source, each emission factor and each activity data randomly selected was multiplied to obtain a sample of the emission of that source. When adding up the emission samples of all the six sources, one sample representing the total emission was obtained. This process was repeatedly run for 10000 times, resulting in a dataset including 10000 total emissions, whose statistics of the median, the mean, the 2.5th percentile and 97.5th percentile values were calculated and therefore the propagation of uncertainty of the total emission at the $95 \%$ confidence interval was obtained.

The above methodology was followed to conduct the uncertainty analysis of the emission factors and activity data of each source. Taking the vehicle source for example, data range of emission factors of motorcycles used for uncertainty analysis was $[4.38,7.30] \mathrm{g} / \mathrm{km}$ (Fu et al., 2001; Hao and Wang, 2007; Li et al., 2003; Wang et al., 2001a, 2001b; Hao et al., 2002; Xie et al., 2006), which best fit the lognormal distribution, with a mean value of $4.79 \mathrm{~g} / \mathrm{km}$ and the standard deviation of $0.45 \mathrm{~g} / \mathrm{km}$. The probability density distribution of the emission factors selected for other vehicle categories were also log-normal distributed. Specifically, the data range of the emission factors of passenger cars was [0.54, 6.08] g/km (Fu et al., 2001; Li et al., 2003; Wang et al., 2001a, 2001b; Hao et al., 2002; He and Wang, 2006; Xie et al., 2006), with a mean value of $1.23 \mathrm{~g} / \mathrm{km}$ and the standard deviation of $2.4 \mathrm{~g} / \mathrm{km}$; the data range of the emission factors of light duty vans was $[0.09,6.47] \mathrm{g} / \mathrm{km}$ ( Li et al., 2003; Wang et al., 2001a, 2001b; Hao et al., 2002; Deng et al., 2000; Fu et al., 2005; He and Wang, 2006; Xie et al., 2006; Wei et al., 2008; Yu and Yu, 2008), with a mean value of $1.40 \mathrm{~g} / \mathrm{km}$ and the standard deviation of $2.1 \mathrm{~g} / \mathrm{km}$; the data range of the emission factors of heavy duty vans was [2.26, 23.0] g/km (Li et al., 2003; Wang et al., 2001a, 2001b; Hao et al., 2002; Xie et al., 2006; Wei et al., 2008), with a mean value of $2.98 \mathrm{~g} / \mathrm{km}$ and the standard deviation of $1.65 \mathrm{~g} / \mathrm{km}$; 


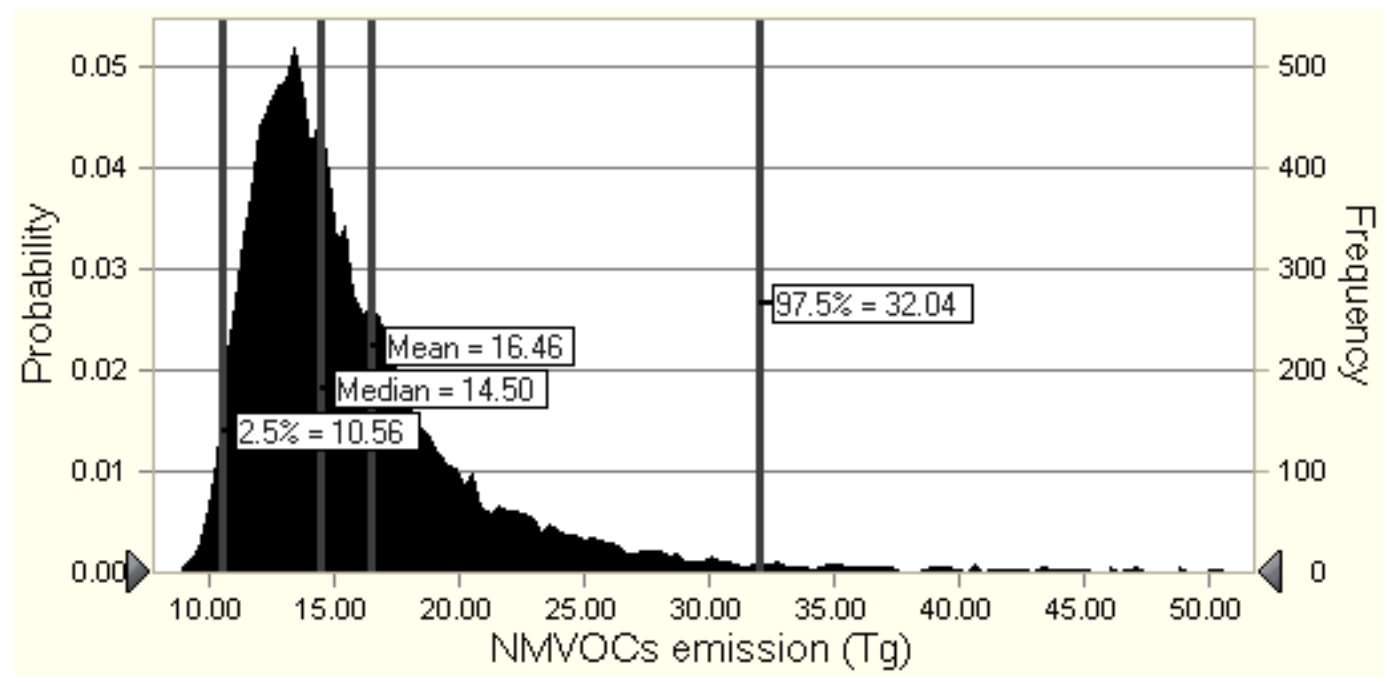

Fig. 11. Probability distribution of China's national NMVOCs emissions in 2005, based on the 10000 Monte Carlo simulations.

and the data range of the emission factors of buses was $[0.78$, 11.2] g/km (Li et al., 2003; Wang et al., 2001a, 2001b; Hao et al., 2002; Xie et al., 2006; Yu and Yu, 2008), with a mean value of $1.21 \mathrm{~g} / \mathrm{km}$ and the standard deviation of $0.94 \mathrm{~g} / \mathrm{km}$.

With respect of those sources with only one sample data of emission factor, we assumed that the emission factors of this source were normally distributed. Since the emission factors were from AP42, we referred to the EPA's evaluation on the emission factors in AP42, when we tried to determine a convincing standard deviation of the log-normal distribution of the emission factors. Based on the EPA's evaluation, the uncertainty of the emission factors was rated from A to $\mathrm{E}$ with the uncertainty increasing accordingly. We therefore converted the letter-grade emission factor ratings of $\mathrm{A}$ to $\mathrm{E}$ to coefficients of variation $(\mathrm{CV})$ of $\pm 5 \%-100 \%, \pm 100 \%-$ $200 \%, \pm 200 \%-300 \%, \pm 300 \%-400 \%$, and $\pm 400 \%-500 \%$, respectively, for the emission factor related normal distributions. For example, the emission factor of surface coating for machine tools is rated $\mathrm{E}$, for which we assumed a $\mathrm{CV}$ value of $\pm 500 \%$. Thus, the mean value of $0.4 \mathrm{~kg}$ per piece and the standard deviation of $2.0 \mathrm{~kg}$ per piece were used.

Regarding those sources which had locally measured emission factors, like the open burning of cornstalk, the locally measured emission factors and those which had been used to estimate China's emission inventory were selected, which included 10 (Li et al., 2007), 15.7 (Streets et al., 2003), 8.7 (Klimont et al., 2002), and $7.0 \mathrm{~g} / \mathrm{kg}$ (Andreae and Merlet, 2001). Since it is believed that the locally measured emission factors could better reflect the actual situation of open burning and thus are more credible, the $\mathrm{CV}$ value of $\pm 25 \%$ was assumed. Therefore, the log-normal distribution with the mean value of $10 \mathrm{~g} / \mathrm{kg}$ and the standard deviation of $2.5 \mathrm{~g} / \mathrm{kg}$ was determined.
Regarding the activity data, the biomass amount of open burning was taken as an example: the estimated biomass amount of open burning in this study was $107.7 \mathrm{Tg}$, while the estimation by Cao et al. (2006) was $131.78 \mathrm{Tg}$. The data range was $[75,150] \mathrm{Tg}$, based on the maximum and minimum ratios of open burning in each province. Thus, the log-normal distribution with a mean value of $107.7 \mathrm{Tg}$ and a standard deviation of $19 \mathrm{Tg}$ was determined.

Based on the above determined statistics of mean values and standard deviations of the probability distribution functions of the emission factors and activity data of each NMVOCs source, the Monte Carlo simulation was repeatedly implemented with new input values randomly selected from within the respective probability distribution of the emission factors and activity data of each source. For each source, each emission factor and each activity data randomly selected was multiplied to obtain a sample of the emission of that source. When adding up the emission samples of all the six sources, one sample representing the total emission was obtained. This process was repeatedly run for 10000 times, resulting in a sample set of 10000 of the total emission, whose statistics of the median, mean, the 2.5 th percentile and 97.5th percentile values were calculated and therefore the propagation of uncertainty of the total emission at the $95 \%$ confidence interval was obtained. Figure 11 illustrates the probability distribution of China's NMVOCs emission inventory in 2005 , the mean value, the 2.5 th percentile value and the 97.5 th percentile value of which were $16.46 \mathrm{Tg}, 10.56 \mathrm{Tg}$ and $32.04 \mathrm{Tg}$, respectively. Therefore, the propagation of uncertainty of the total emission in 2005 at the $95 \%$ confidence interval was about $[-36 \%, 94 \%]$. Results showed that the emission factors of burning cornstalk and firewood, of the production of synthetic fibre, and of the surface coating of business machines were most sensitive to the uncertainty result. 


\section{Summary and conclusions}

NMVOCs emission inventories including six anthropogenic sources were estimated for the period of 1980-2005, based on statistical data at county and provincial level from yearbooks and relevant research and literatures. The emission inventories were further allocated to the county level and gridded at a high resolution of $40 \mathrm{~km} \times 40 \mathrm{~km}$ by means of the GIS methodology.

Results showed that China's NMVOCs emissions had increased by 4.2 times at a yearly average rate of $10.6 \%$ from $3.91 \mathrm{Tg}$ in 1980 to $16.49 \mathrm{Tg}$ in 2005, which had exceeded that in the US in 2005. The major sources of NMVOCs emissions in China in 2005 were motorcycles, biofuel burning, heavy duty vans, synthetic fibre production, biomass open burning, and industrial and commercial consumption of fossil fuel. Therefore, these sources should be emphasized in priority when designing control and reduction regulations for NMVOCs emissions in China.

There was notable discrepancy of the source contributions to the total emissions during the period of 1980-2005: vehicular emission had a tremendous increase from $5.2 \%$ to $33.3 \%$; emission of fossil fuel combustion experienced an increase from $8.7 \%$ to $12.0 \%$; emission of industrial processes increased from $11.3 \%$ to $16.7 \%$; while emissions of biomass burning, storage and transport, and solvent utilization had a decrease from $41.0 \%$ to $23.0 \%$, from $6.6 \%$ to $3.3 \%$, and from $28.0 \%$ to $11.4 \%$, respectively. However, the NMVOCs emissions of these sources continued growing during the period, which coincided well with the economic growth in China, as revealed by the correlation analysis of China's NMVOCs emissions and the GDP. This meant that rapid economic development in China had stimulated the increase of NMVOCs emissions. Despite the introduction and implementation of stricter fuel and emission regulations for vehicles, the growth of NMVOCs emissions in China had yet to be brought under control, due to the substantial increase of vehicle population and road length in China. Moreover, these strict fuel and emission regulations were mainly implemented in cities, which caused the transfer of high emission vehicles from cities to underdeveloped regions and the vast rural areas. Therefore, the total NMVOCs emissions did not decrease, but merely transferred from one region to another.

The spatial distribution of gridded emissions based on the GIS methodology revealed that remarkably high emission areas mainly concentrated in the middle reaches of the Yangtze River, and the northeastern, northern coastal, eastern coastal and southern coastal areas, which altogether cover $35.2 \%$ of China's territory, but generated $59.4 \%$ of the total emissions. On the contrary, the western provinces of Xizang, Shaanxi, Gansu, Qinghai, Ningxia, and Xinjiang covering $44.6 \%$ of the territory, contributed only $5.8 \%$ of the total emissions. Besides, the capital cities in China covering merely $4.5 \%$ of China's territory, were responsible for $24.9 \%$ of the national emissions of NMVOCs in 2005. Moreover, annual variation of the spatial distribution of emissions revealed that the regions of high emission intensity had been expanding from eastern, southern and northeastern areas to the northwestern areas. Therefore, NMVOCs emissions in China continued growing year by year, and some high emission intensity regions appeared and became concentrated. Emission intensity in some individual regions was especially high, and showed an increasing trend of emission intensity, along with the expansive trend of the area of these high emission intensity regions.

Acknowledgements. This work was supported by a grant from the Major State Basic Research Development Program of China (No. 2002CB211600), and the Ph.D. Program Foundation of Ministry of Education of China (No. 20060001057). We would like to thank Yuh-Shan Ho, J. Zhang, and Z. Liu for their helpful assistance and suggestions, and Jiang Zhihua (National Bureau of Statistics) for providing methods on market survey and forecast.

Edited by: R. Cohen

\section{References}

All China Strategic Research Ltd.: China Market Yearbook (1999_ 2006 editions), Foreign Language Press, Beijing, 1999-2006.

Altshuller, A. P.: The production of carbon-monoxide by the homogeneous $\mathrm{NO}_{\mathrm{x}}$-induced photooxidation of volatile organiccompounds in the troposphere, J. Atmos. Chem., 13, 155-182, 1991.

Andreae, M. O. and Merlet, P.: Emission of trace gases and aerosols from biomass burning, Global Biogeochem. Cy., 15(4), 955-966, 2001.

Atkinson, R. and Arey, J.: Atmospheric degradation of volatile organic compounds, Chem. Rev., 108, 4605-4638, 2003.

Boeglin, M. L., Wessels, D., and Henshel, D.: An investigation of the relationship between air emissions of volatile organic compounds and the incidence of cancer in Indiana counties, Environ. Res., 100, 242-254, 2006.

Cai, H. and Xie, S. D.: Estimation of vehicular emission inventories in China from 1980 to 2005, Atmos. Environ., 41, 8963-8979, 2007.

Cao, G. L., Zhang, X. Y., Wang, D., and Zheng, F. C.: Inventory of atmospheric pollutants discharged from biomass burning in China continent, China Environ. Sci., 25(4), 389-393, 2005.

Cao, G. L., Zhang, X. Y., Zheng, F. C., and Wang, Y. Q.: Estimating the quantity of crop residues burnt in open field in China, Resour. Sci., 28(1), 9-13, 2006.

China Automobile Industry Association: China Automobile Industry Yearbook, China Machine Press, Beijing, 2006.

Cilek, C. M. and Kohout, E.: Estimating monthly and state-level $\mathrm{NO}_{\mathrm{x}}, \mathrm{SO}_{2}$, VOC and $\mathrm{CO}_{2}$ emissions using the MSCET database, annual Pittsburgh conference on modeling and simulation; Pittsburgh, PA (United States); DOE Project, 30 April-1 May 1992, 1992.

Deng, S. X., Chen, J., and Li, B. C.: Emission factors of CO, $\mathrm{HC}$ and $\mathrm{NO}_{\mathrm{x}}$ from motor vehicles on urban main road in China, China Environ. Sci., 20(1), 82-85, 2000. 
European Environment Agency (EEA): COPERT III-computer programme to calculate emissions from road transport. Methodology and emission factors (version 2.1), Technical Report No. 49, 2000.

Editorial department of China agriculture yearbook: China Agriculture Yearbook (1996, 2001, 2006 Editions), China Agriculture Press, Beijing, 1996, 2001, 2006.

Environmental Protection Agency (EPA): Compilation of air pollutant emission factors (AP42), Fifth Edition, Chapter 1-13, 1995.

Environmental Protection Agency (EPA): Emissions factor uncertainty assessment, http://www.epa.gov/ttn/chief/efpac/ uncertainty.html, 2007.

Environmental Protection Agency (EPA): National emission inventory (NEI) air pollutant emissions trends data, $\quad$ http://www.epa.gov/ttn/chief/trends/trends06/ nationaltier1upto2006basedon2002finalv2.1.xls, 2007.

Field, R. A., Goldstone, M. E., Lester, J. N., and Perry, R.: The sources and behavior of tropospheric anthropogenic volatile hydrocarbons, Atmos. Environ., 26A, 2983-2996, 1992.

Fu, X. Q., Weng, Y. B., Qian, F. Z., Ye, W. B., Jin, Y. X., and Chen, Y. Y.: Study of the VOC source profile and benzene compounds emission of various motor vehicles, Acta Scientiae Circumstantiae, 6, 1056-1062, 2008.

Fu, L. L., Shao, M., Liu, Y., Liu, Y., Lu, S. H., and Tang, D. G.: Tunnel experimental study on the emission factors of volatile organic compounds (VOCs) from vehicles, Acta Scientiae Circumstantiae, 25(7), 879-885, 2005.

Fu, L. X., Hao, J. M., He, D. Q., and He, K. B.: Assessment of vehicular pollution in China, J. Air Waste Manage., 51, 656-668, 2001.

Guenther, A., Hewitt, C. N., Erickson, D., Fall, R., Geron, C., Graedel, T., Harley, P., Klinger, L., Lerdau, M., Mckay, W. A., Pierce, T., Scholes, B., Steinbrecher, R., Tallamraju, R., Taylor, J., and Zimmerman, P.: A global-model of natural volatile organic compound emissions, J. Geophys. Res., 100(D5), 88738892, 1995

Hao, J. M., Wu, Y., Fu, L. X., He, D. Q., and He, K. B.: Study of the urban vehicular emission control program system in China, J. Appl. Meteorol., 13, 195-203, 2002.

Hao, M. and Wang, D. D.: Study of the urban vehicular pollution control strategy in China, Sci. Technol. Inf., 25, 143-144, 2007.

He, C. Y. and Wang, Q. D.: Vehicle emission factors determination using CMEM in Beijing, Res. Environ. Sci., 19(1), 109-112, 2006.

He, D. Q.: Study on urban vehicular pollution assessment system and emission control target, Tsinghua University Doctor Thesis, 1999.

Hu, B. X., Zhu, H., and Tan, W. X.: A detailed list for exhaust in development models of automobile technology in China, J. Wuhan Automotive Polytechnic Univ., 2, 99-102, 2002.

Klimont, Z., Streets, D. G., Gupta, S., Cofala, J., Fu, L. X., and Ichikawa, Y.: Anthropogenic emissions of non-methane volatile organic compounds in China, Atmos. Environ., 36, 1309-1322, 2002.

Li, M. X., Han, Z. H., and Wu, J.: Analysis and proposal on development trends of airport construction in China, Rev. Economic Res., 43, 13-27, 2000.
Li, X. H., Wang, S. X., Duan, L., Hao, J., Li, C., Chen, Y. S., and Yang, L.: Particulate and trace gas emissions from open burning of wheat straw and corn stover in China, Environ. Sci. Technol., 41, 6052-6058, 2007.

Li, W., Fu, L., X., Hao, J., M., Ma, H., Li, S. Q., and Hu, W.: Emission inventory of 10 kinds of air pollutants for road traffic vehicles in China, Urban Env. Urban Ecol., 16, 36-38, 2003.

Loibl, W., Orthofer, R., and Winiwarter, W.: Spatially disaggregated emission inventory for anthropogenic NMVOC in Australia, Atmos. Environ., 27A, 2575-2590, 1993.

Lubkert, B. and Detilly, S.: The OECD map emission inventory for $\mathrm{SO}_{2}, \mathrm{NO}_{\mathrm{x}}$ and VOC in western-Europe, Atmos. Environ., 23, 3-15, 1989.

National Bureau of Statistics (NBS): China Energy Statistical Yearbook (1986, 1987, 1991-1996, 1997-1999, 2000-2002, 2006 editions), China Statistics Press, Beijing, 1986-2006.

National Bureau of Statistics: China Statistical Yearbook (19812006 editions), China Statistics Press, Beijing, 1981-2006.

National Bureau of Statistics team of rural socio-economic investigation: China Rural Statistical Yearbook (1985-2006 editions), China Statistics Press, Beijing, 1985-2006.

National Satellite Meteorological Center: Report on meteorological satellite fire monitoring, 4, 2005.

Ohara, T., Akimoto, H., Kurokawa, J., Horii, N., Yamaji, K., Yan, X., and Hayasaka, T.: An Asian emission inventory of anthropogenic emission sources for the period 1980-2020, Atmos. Chem. Phys., 7, 4419-4444, 2007, http://www.atmos-chem-phys.net/7/4419/2007/.

Olivier, J. G. J., Bouwman, A. F., Maas, C. W. M. van der Berdowski, J. J. M., Veldt, C., Bloos, J. P. J., Visschedijk, A. J. H., Zandveld, P. Y. J., and Haverlag, J. L.: Description of EDGAR Version 2.0: A set of global emission inventories of greenhouse gases and ozone-depleting substances for all anthropogenic and most natural sources on a per country basis and on 1 degree x 1 degree grid, RIVM report 771060 002, 1996.

Olivier, J. G. J., Berdowski, J. J. M., Peters, J. A. H. W., Bakker, J., Visschedijk, A., J. H., and Bloos, J. P. J.: Applications of EDGAR including a description of EDGAR 3.2: reference database with trend data for 1970-1995, RIVM report 773301001/NRP report 410200 051, 2001/2002.

Piccot, S. D., Watson, J. J., and Jones, J. W.: A global inventory of volatile organic compound emissions from anthropogenic sources, J. Geophys. Res., 97(D9), 9897-9912, 1992.

Ren, C. F.: China Industrial Economic Statistic Yearbook (19882006 editions), China Statistics Press, Beijing, 1988-2006.

Seinfeld, J. H., Pandis, S. N., and Noone, K.: Atmospheric chemistry and physics: from air pollution to climate change, Phys. Today, 51(10), 88, doi:10.1063/1.882420, 1998.

Shen, M. J., Hao, J. M., and Wang, L. T.: VOC emission situation and control measures of gas station in China, Environ. Sci., 27(8), 1473-1478, 2006.

Song, X. Y. and Xie, S. D.: Development of vehicular emission inventory in China, Environ. Sci., 27, 1041-1045, 2006.

State Forestry Administration: China Forestry Statistical Yearbook 2006, China Forestry Publishing House, 2007.

Tonooka, Y., Kannari, A., Higashino, H., and Murano, K.: NMVOCs and CO emission inventory in East Asia, Water Air Soil Poll., 130, 199-204, 2001. 
Wang, B. G., Zhang, Y. H., Wu, Z. Q., and Chen, L. Y.: Tunnel test for motor vehicle emission factors in Guangzhou, Res. Environ. Sci., 14(4), 13-16, 2001a.

Wang, B. G., Zhang, Y. H., Zhu, C. J., Yu, K. H., Chen, L. Y., and Chen, Z. Y.: A study on city motor vehicle emission factors by tunnel test, Environ. Sci., 22(2), 55-59, $2001 \mathrm{~b}$.

Xie, S. D., Song, X. Y., and Shen, X. H.: Calculating vehicular emission factors with COPERT III model in China, Environ. Sci., 27, 415-419, 2006.

Wei, W., Wang, S. X., Chatani, S., Klimont, Z., Cofala, J., and Hao, J. M.: Emission and speciation of non-methane volatile organic compounds from anthropogenic sources in China, Atmos. Environ., 42, 4976-4988, 2008.

Xia, Y. M. and Sun, L. K.: Environmental Pollution Control during Oil Storage and Transport, China Petrochemical Press, Beijing, 1992.

Yang, B.: China Light Industry Yearbook 1949-1983, Encyclopedia of China Publishing House, Beijing, 1985.

Yang, Z. P.: China Light Industry Yearbook (1985-2006 editions), China Light Industry Yearbook Press, 1985-2006.
Ye, S. B., Wang, Q. D., and He, X.: Tianjin on-road vehicle activity study, Journal of Beijing Technology and Business University (Natural Science Edition), 2, 28-31, 2007.

Yevich, R. and Logan, J. A.: An assessment of biofuel use and burning of agricultural waste in the developing world, Global Biogeochem. Cy., 17(4), 1095, doi:10.1029/2002GB001952, 2003.

Yu, Y. C. and Yu, M. Y.: Estimation and forecast of for-hire motor vehicle emission volume, J. Highway and Transportation Res. Dev., 6, 154-158, 2008.

Zachariadis, T. and Samaras, Z.: An integrated modeling system for the estimation of motor vehicle emissions, J. Air Waste Manage., 49, 1010-1026, 1999.

Zhang, S. Y., Bai, Y. H., and Li, J. L.: Distribution of $\mathrm{SO}_{2}, \mathrm{NO}_{\mathrm{x}}$, $\mathrm{CO}$ and $\mathrm{HC}$ emissions from fixed combustion sources in Yangtze River Delta, Yunnan Environ. Sci., 19, 195-200, 2000.

Zhang, Y. H., Shao, M., and Yu, K. H.: Vehicle emissions, enviromental impact and control, Chemical Industry Press, Beijing, 2004. 